\title{
26. CALCAREOUS NANNOFOSSILS FROM THE CRETACEOUS OF THE DEEP IVORIAN BASIN
}

\author{
David K. Watkins, ${ }^{2}$ Samir Shafik, ${ }^{3}$ and I.C. Shin ${ }^{4}$
}

\begin{abstract}
Micropaleontological investigation of four sites drilled by Ocean Drilling Program Leg 159 on the Côte d'Ivoire-Ghana Margin indicates that the initial invasion of oceanic surface waters into the Deep Ivorian Basin, as indicated by the presence of calcareous nannofossils, occurred during the late Albian. The nature of these assemblages suggests that these first Cretaceous oceanic surface waters were warm and relatively high in nutrients. These upper Albian sediments were deposited prior to significant tectonism at some of the sites, as indicated by their structurally deformed nature. The likely age of this tectonism is Cenomanian. The Upper Cretaceous consists of condensed sequences of hemipelagic carbonates and phosphatic hardgrounds with very low sediment accumulation rates overlain, at Site 959, by non-calcareous claystones. These Turonian through Santonian hemipelagic carbonates contain nannofossil assemblages that suggest low surface water nutrient content, resulting in starved basin conditions.
\end{abstract}

\section{INTRODUCTION}

Part of the mission of Ocean Drilling Program (ODP) Leg 159 was to investigate the early (Cretaceous) tectonic and paleoceanographic history of the Côte d'Ivoire-Ghana Margin and the Deep Ivorian Basin (Fig. 1). This area is of critical importance in the history of the modern Atlantic Ocean, as it was one of the last areas to open during the initial spreading phase. The connection between the nascent North and South Atlantic Ocean changed drastically as the Romanche Fracture Zone was activated during the mid-Cretaceous. The Cretaceous sedimentary record of this area yields important clues to the evolution of the equatorial Atlantic during this critical interval.

The purpose of this report is to biostratigraphically subdivide the Cretaceous sedimentary rocks recovered from the drilling of four sites using calcareous nannofossils, as well as to analyze the nature of the calcareous nannofossil assemblages to shed light on the surface water conditions that existed during the Cretaceous.

\section{METHODS}

The nannofossil biostratigraphy presented in this paper is largely drawn from examination of assemblages using the light microscope. Examination of some assemblages with a JEOL-T330 scanning electron microscope (SEM) was also necessary for solving taxonomic problems.

Nannofossil abundance and preservation varied widely in the Leg 159 material. Much of the Upper Cretaceous material from Sites 959 and 960 contains sparse nannofossil assemblages diluted by other sedimentary components. Concentration of nannofossils by gravitational settling was used for some of this material. In other cases, some of the lithologies contain abundant to common nannofossils. Smear slides of raw sediment from these sites were used in determining nannofossil abundance (as a component of the sediment), nannofossil

${ }^{1}$ Mascle, J., Lohmann, G.P., and Moullade, M. (Eds.), 1998. Proc. ODP, Sci. Results, 159: College Station, TX (Ocean Drilling Program).

${ }^{2}$ Department of Geology, University of Nebraska-Lincoln, Lincoln, NE 685880340,U.S.A.dwatkins@unlinfo.unl.edu

${ }^{3}$ Marine Science and Petroleum Geology Program, Australian Geological Survey Organization, GPO Box 378, Canberra, ACT 2601, Australia.

${ }^{4}$ Korea Ocean Research and Development Institute, Ansan, P.O. Box 29, Seoul 425600 Korea. preservation, and the qualitative relative abundance of individual nannofossil taxa.

Abundance of nannofossils as a component of the sediment, as determined by examination of smear slides, are as follows:

$$
\begin{aligned}
& A=>50 \% \text { of sediment by volume; } \\
& C=15 \%-50 \% \text { of sediment by volume; } \\
& F=1 \%-15 \% \text { of sediment by volume; and } \\
& R=<1 \% \text { of sediment by volume. }
\end{aligned}
$$

Relative abundances for individual nannofossil taxa are as follows:

$A=$ abundant $(1-10$ specimens per field of view at $1500 \times)$;

$\mathrm{C}=$ common ( 1 specimen per $2-10$ fields of view at $1500 \times)$;

$\mathrm{F}=$ few $(1$ specimen per $11-100$ fields of view at $1500 \times)$;

$\mathrm{R}=$ rare $(1$ specimen per $101-1000$ fields of view at $1500 \times)$; and

$?=$ questionable presence of this species.

An average state of preservation was assigned to each sample according to the following criteria:

$\mathrm{G}(\mathrm{good})=$ most specimens exhibit little or no secondary alteration;

$\mathrm{M}($ moderate $)=$ specimens exhibit the effects of secondary alteration from etching and/or overgrowth (identification of species not impaired); and

$\mathrm{P}($ poor $)=$ specimens exhibit profound effects of secondary alteration from etching and/or overgrowth (identification of species impaired, but possible in some cases).

Taxa included in this report are listed in the Appendix. Bibliographic references for these taxa are found in Loeblich and Tappan (1966, 1968, 1969, 1970a, 1970b, 1971, 1973), van Heck (1979a, 1979b, 1980a, 1980b, 1981a, 1981b, 1982a, 1982b, 1983), and Steinmetz (1984a, 1984b, 1985a, 1985b, 1986, 1987a, 1987b, 1988a, 1988b, 1989). Any taxa not cited therein are cited in the references of this paper.

Age determinations and correlations of the Leg 159 nannofossil assemblages use a modified version of the Cretaceous nannofossil zonation of Sissingh (1977) as modified and codified by PerchNielsen (1985). Specifically, Zone CC12 is herein divided by the presence of Liliasterites angularis in the upper part of the zone. Stradner and Steinmetz (1984) recognized this biostratigraphic inter- 
Figure 1. Location of the ODP Leg 159 sites.

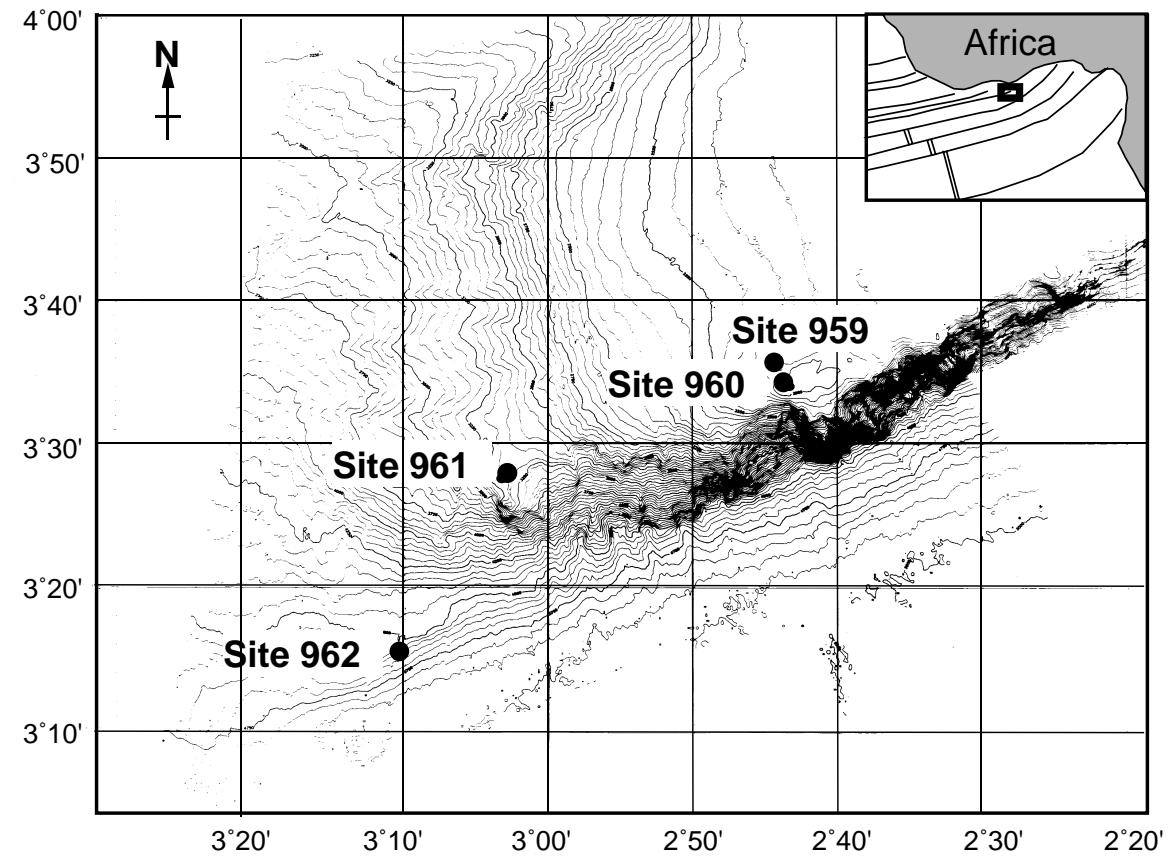

val and defined it as the Liliasterites angularis Zone from sediments in the nearby Angola Basin. It is recognized herein at the subzonal level. In addition, the Marthasterites furcatus Zone (CC13) is generally divided into two subzones based upon the first occurrence of Lithastrinus septenarius (e.g., Perch-Nielsen, 1985). However, this species can be difficult to consistently differentiate from Lithastrinus moratus. Indeed, Varol (1992) equates the two taxa under the name Lithastrinus moratus. An alternate subzone can be recognized in the Leg 159 material based on the occurrence of Liliasterites atlanticus (Fig. 2). This interval was noted previously by Stradner and Steinmetz (1984), who identified it in Site 530 material from the nearby Angola Basin. Zone CC10 is subdivided based on the last occurrence of Axopodorhabdus albianus, following the work of Watkins (1985) and Bralower (1988).

Lithologic and petrographic data used here consist of personal observations as well as the descriptions and core photographs in Mascle, Lohmann, Clift, et al. (1996). Important taxa are documented in Plates 1-4, illustrating the taxonomic concepts and state of preservation of the nannofossils.

\section{RESULTS \\ Site 959}

Four holes were drilled at Site 959 of which only one (Hole 959D) penetrated to Cretaceous sediment. Much of the sediment lying below the demonstrable upper Paleocene nannofossil claystone in Section 159-959D-44R-3 is noncalcareous and, therefore, undateable by calcareous microfossils. Shipboard palynological determinations suggest that the Cretaceous/Tertiary boundary lies near the base of Core 159-959D-48R (870 mbsf). The underlying non-calcareous claystone in the interval from Core 159-959D-49R through Section 159-959D-65R-2 (870 to $1027 \mathrm{mbsf}$ ) apparently spans the Campanian and Maastrichtian. The underlying stratigraphic interval from Section 159-959D-65R-3 to 71R-1 (1027 to 1082 mbsf) includes calcareous hemipelagic sediments that contain calcareous microplankton fossils, permitting more precise biostratigraphic placement (Table 1). Below that, the underlying sequence comprising most of Cores 159-959D-71R through 78R (1082-1159 mbsf) consists of

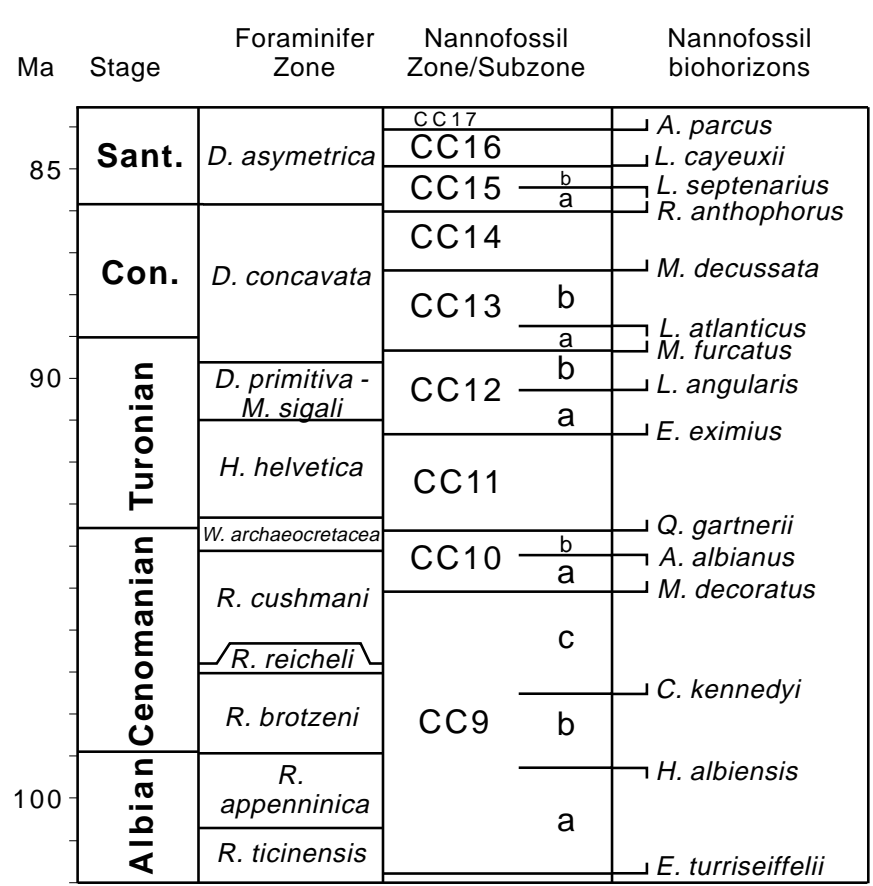

Figure 2. Calcareous nannofossil biostratigraphy used in this paper. San = Santonian; Con. $=$ Coniacian.

quartz sandstone, siltstone, and claystone with terrestrial plant debris that is barren of calcareous microplankton fossils and is undated.

The interval from 159-959D-69R through 71R-1, 0-1 cm (1063 to $1081.7 \mathrm{mbsf}$ ) consists of limestone and dolomitic limestone of variable texture, including skeletal wackestone, packstone, and grainstone that include abundant fragments of neritic invertebrate skeletal material. This shallow-water carbonate material is believed to have been transported downslope from a nearby carbonate shelf. Some of this shallow-water carbonate material (notably in Core 159- 


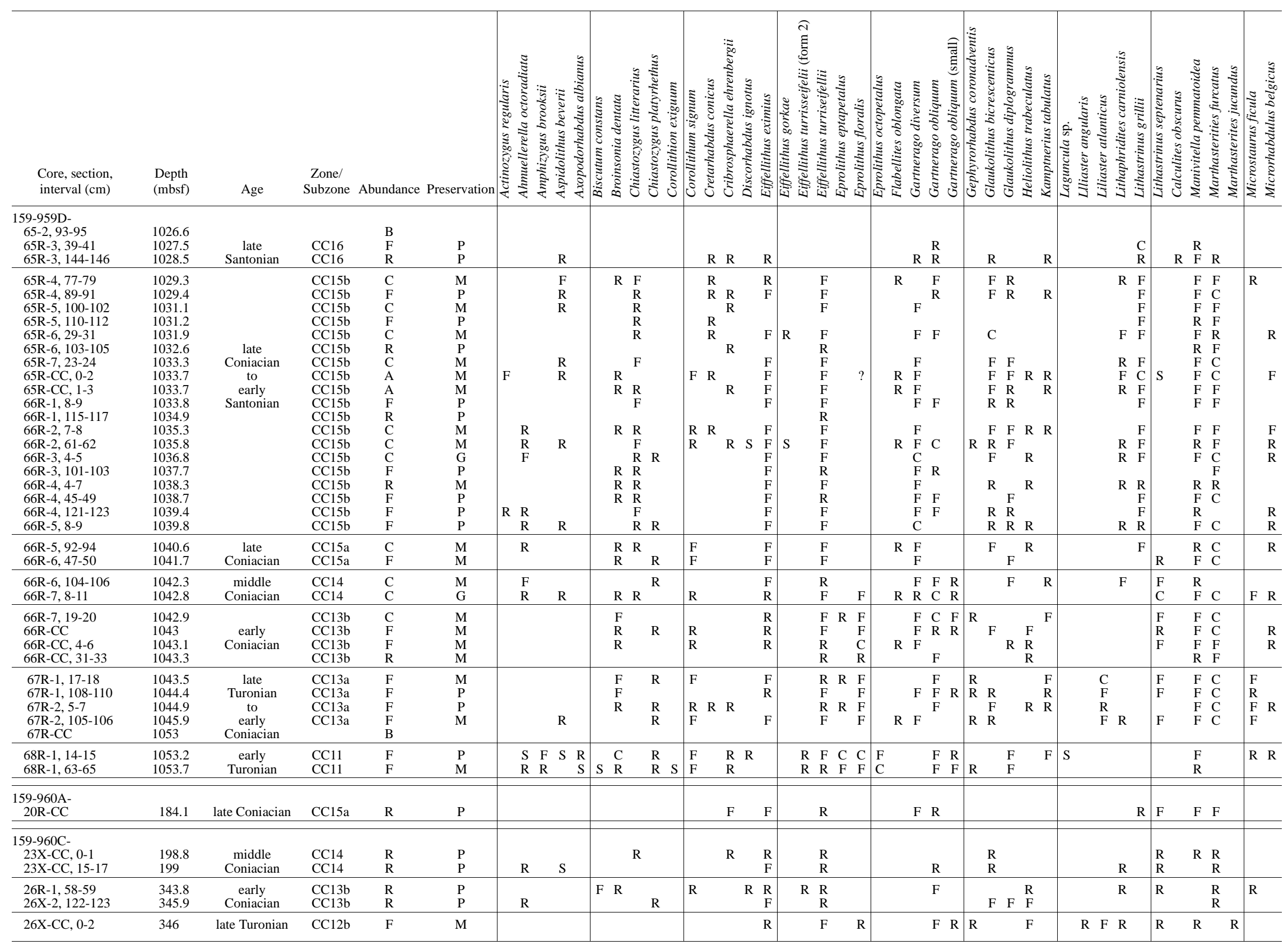




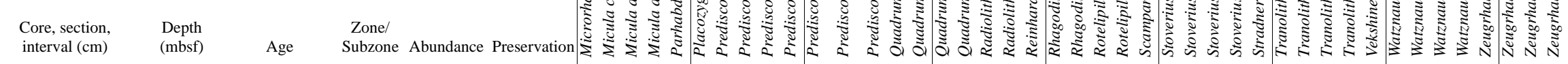

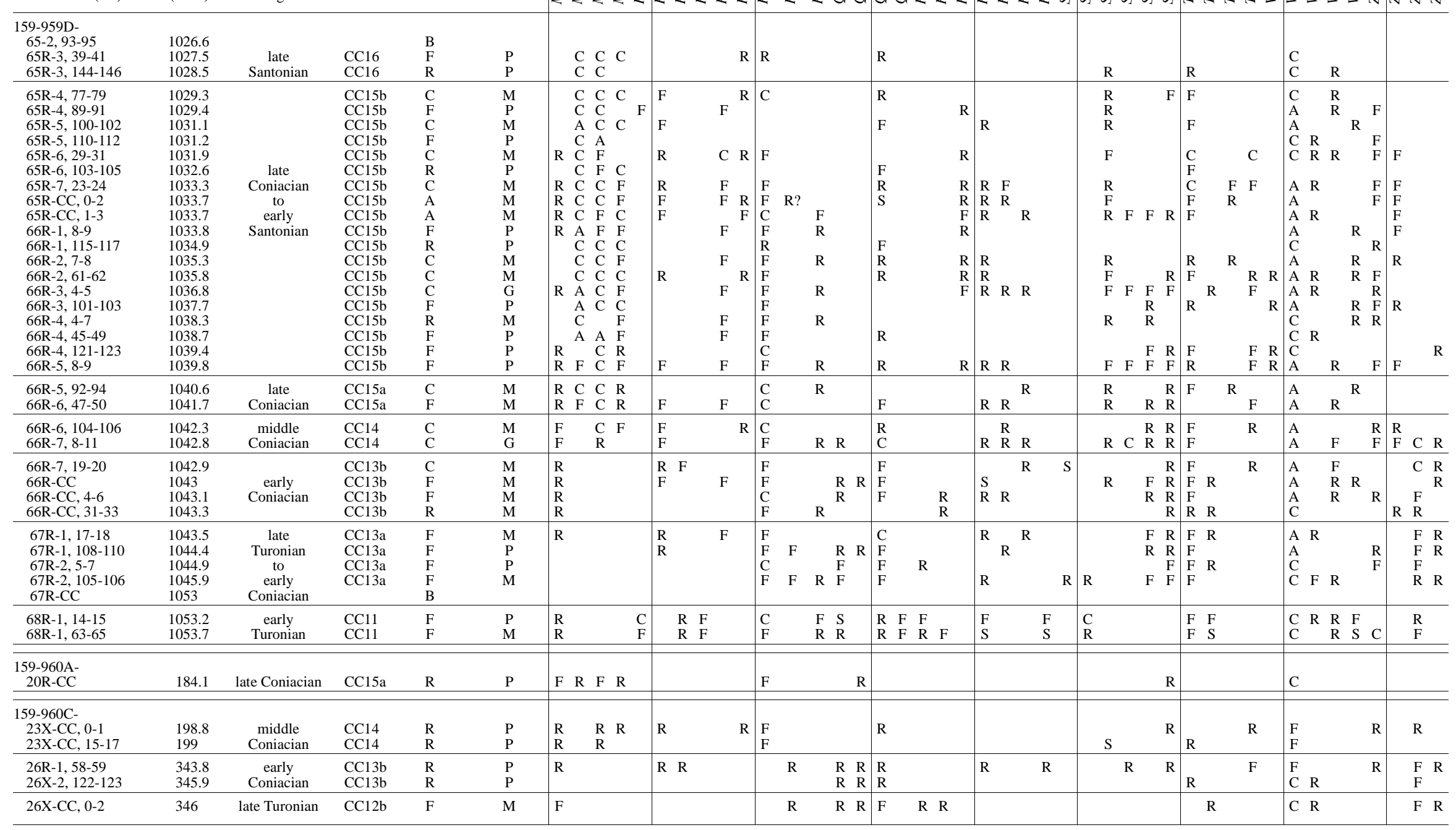


959D-69R) is quite sandy (up to $50 \%$ fine to very coarse quartz sand); whereas, some of it (as in Core 159-959D-70R) is essentially quartz free. Calcareous nannofossils occur in isolated samples of dark, calcareous wackestone consisting of fine-grained carbonate grains in a matrix of nannofossil claystone. Nannofossil assemblages in this interval are uniformly sparse and poorly preserved. The abundance of calcareous silt and fine sand-sized grains indicates that the initial flux of pelagic calcareous microfossils was a minor component of the accumulating sediment. This same abundance of neritic-derived carbonate, at least some of which was originally metastable carbonate phases, apparently accelerated the diagenetic process, rendering many calcareous nannofossil specimens unrecognizable because of severe overgrowth and, to a lesser extent, dissolution. Calcareous nannofossil assemblages in this interval are strongly dominated by Watznaueria barnesae, which in this case reflects the significant diagenetic overprint. Other, generally rare, species include Axopodorhabdus albianus, Prediscosphaera columnata $(<5 \mu \mathrm{m})$, Rhagodiscus angustus, Eprolithus floralis, Tranolithus exiguus, Ellipsogelasphaera britannica, and Eiffellithus turriseiffellii. The co-occurrence of these species without Hayesites albiensis, Crucicribrum anglicum, and Corollithion kennedyi suggests a zonal assignment of CC9b of latest Albian to early Cenomanian age. However, the absence of $H$. albiensis and C. anglicum may be preservational, so that this material may also be from Subzone CC9a of late Albian age.

It should be noted that the lowest nannofossil-bearing sample (159-959D-71R-1, 0-1 cm) was derived from disturbed sediment lying atop a highly fractured interval of light-gray quartz sandstone. The petrography of the nannofossil-bearing sediment is not the same as the fine-grained material of the underlying clastic sequence but is consistent with the fine-grained material from the overlying carbonate sequence. Thus, the age of the clastic sediment (lying below Sample 159-959D-71R-1, $1 \mathrm{~cm}$ ) may be significantly different from that (Subzone CC9b) of the overlying carbonate sequence.

Core 159-959D-68R consists of calcareous sandstone with two interbeds (at 68R-1, 14-16 and 93-105 cm) of conglomerate composed of phosphatic and glauconitic pebbles, inoceramid prism bundles, and minor quartz sand. These are interpreted as remnants of hardground beds. At least part of the thicker interval (159-959D$68 \mathrm{R}-1,93-105 \mathrm{~cm})$ is interpreted to be in place, although the thinner interval (159-959D-68R-1, 14-16 cm) appears to be wholly remobilized following the destruction of a pre-existing hardground. Scattered phosphatic pebbles and inoceramid bundles occur floating in a calcareous sandstone matrix throughout the interval (159-959D-68R$1,17-92 \mathrm{~cm}$ ) between the two conglomerate beds.

Calcareous nannofossil assemblages within Core 159-959D-68R include several taxa indicative of an early Turonian age (Zone CC11) such as Ahmuellerella octoradiata, Eprolithus octopetalus, Quadrum gartnerii, and Quadrum intermedium (Table 1). The presence of these forms, in the absence of Eiffellithus eximius, indicate Zone CC11. Rare specimens of Axopodorhabdus albianus occur throughout this interval. This species is known to disappear prior to the Cenomanian/Turonian boundary (at the top of Subzone CC10a as herein used), so its presence here is attributed to reworking. The most likely source for these recycled specimens is the upper Albian to lower Cenomanian material lying immediately below the lower Turonian in this area.

Core 159-959D-67R consists of a fine-grained sandy carbonate with dolomite grains abundant in the lower part of the core (below Section 67R-1, $90 \mathrm{~cm}$ ) and calcite grains dominant in the upper part (interval 67R-1, 0-90 cm) of the core. These fine sand-sized carbonate grains are surrounded by a matrix of nannofossil claystone. Frequent, moderately to poorly preserved nannofossils in this interval include Eiffellithus eximius, Liliasterites atlanticus, Marthasterites furcatus, Quadrum eneabrachium, and Quadrum gartnerii but not Micula spp. This association indicates Subzone CC13a of late Turonian to early Coniacian age.
Core 159-959D-66R contains a complex sequence of nannofossil claystones and phosphatic hardgrounds with at least four nannofossil subzones represented. Samples 159-959D-66R-7, 19-20 cm through 67R-CC, 31-33 cm contain Eiffellithus eximius, Marthasterites furcatus, and Quadrum gartnerii but no specimens of either Micula or Liliasterites. This association indicates Subzone CC13b of early Coniacian age. This interval is separated from the overlying sequence by a prominent phosphatic hardground. Overlying the hardground, a thin $(<1 \mathrm{~m})$ interval contains calcareous nannofossil assemblages with Micula decussata including many of the transitional forms that generally occur near its stratigraphic base. The presence of these forms, and their associated species, indicate Zone CC14 of middle Coniacian age. This middle Coniacian interval includes at least one horizon of phosphatic conglomerate presumably derived from the local destruction of a phosphatic hardground. This middle Coniacian interval is bounded on the top by a thin phosphatic hardground/ pebble bed. Overlying this is a thin $(<1 \mathrm{~m})$ interval of nannofossil claystone characterized by alternating laminated and nonlaminated intervals on a decimeter scale. The laminated horizons are generally richer in pelagic carbonate, whereas, the non-laminated sequences are carbonate-poor. This interval contains few to common Micula concava, as well as Micula decussata and Lithastrinus moratus/ septenarius, but lacks Reinhardtites anthophorus and Lithastrinus grillii. This association is definitive for Subzone CC15a of late Coniacian age.

Interval 159-959D-65R-3, 89-91 cm, through 66R-5, 8-9 cm, contains Micula concava, Micula decussata, and Reinhardtites anthophorus but lacks Lithastrinus septenarius, indicating Subzone $\mathrm{CC} 15 \mathrm{~b}$ of late Coniacian to early Santonian age. Lithastrinus grillii occurs consistently through this interval. This interval also exhibits the irregular alternation of laminated and nonlaminated horizons (Fig. 3). In general, the laminated intervals contain abundant, wellpreserved nannofossil assemblages, whereas, the nonlaminated intervals have fewer, more poorly preserved nannofossil assemblages. Near the top of the nannofossil claystone interval (in Section 159959D-65R-3), pelagic carbonate becomes progressively rare, with increased etching of the calcareous nannofossils. Sedimentary rocks are noncalcareous just above Sample 159-959D-65R-3, $88 \mathrm{~cm}$.

\section{Site 960}

The Cretaceous of Site 960 was drilled twice: once with continuous coring (Hole 960B) and once with spot coring (Hole 960C). Calcareous microplankton fossils occur only in a part of the sequence, from approximately 184 to 346 mbsf. Even within this interval, calcareous nannofossils are present only as rare, poorly preserved specimens (Table 1) in highly isolated and separated samples of finegrained sediment. The vast majority of the recovered sediment in this 162-m section consists of skeletal grainstone and packstone with variable content of quartz sand. The skeletal grains include bivalve, echinoderm, stromatoporoid, and calcareous algal debris. This material is interpreted to be allochthonous deposits of shallow-water material that has been transported into deeper marine settings (Mascle, Lohmann, Clift, et al., 1996). The upper part of this interval (approximately 184-262 mbsf) contains a significant component of mediumgrained, subrounded to subangular quartz sand. The lower portion (approximately 271-330 mbsf) is essentially free of quartz sand.

The few horizons that contain calcareous nannofossils indicate that this sequence is coeval with the Upper Cretaceous sequence of Site 959. Samples from Core 960C-26X-CC (346-352 mbsf) yield sparse, moderately preserved nannofossil assemblages that include Eiffellithus eximius, Liliasterites angularis, Liliasterites atlanticus, and Quadrum gartnerii. Rare specimens attributable to Marthasterites jucundus occur in these samples. The transitional nature of these rare forms, as well as the abundance of both species of Liliasterites, suggest that these samples are from near the top of upper Turonian 


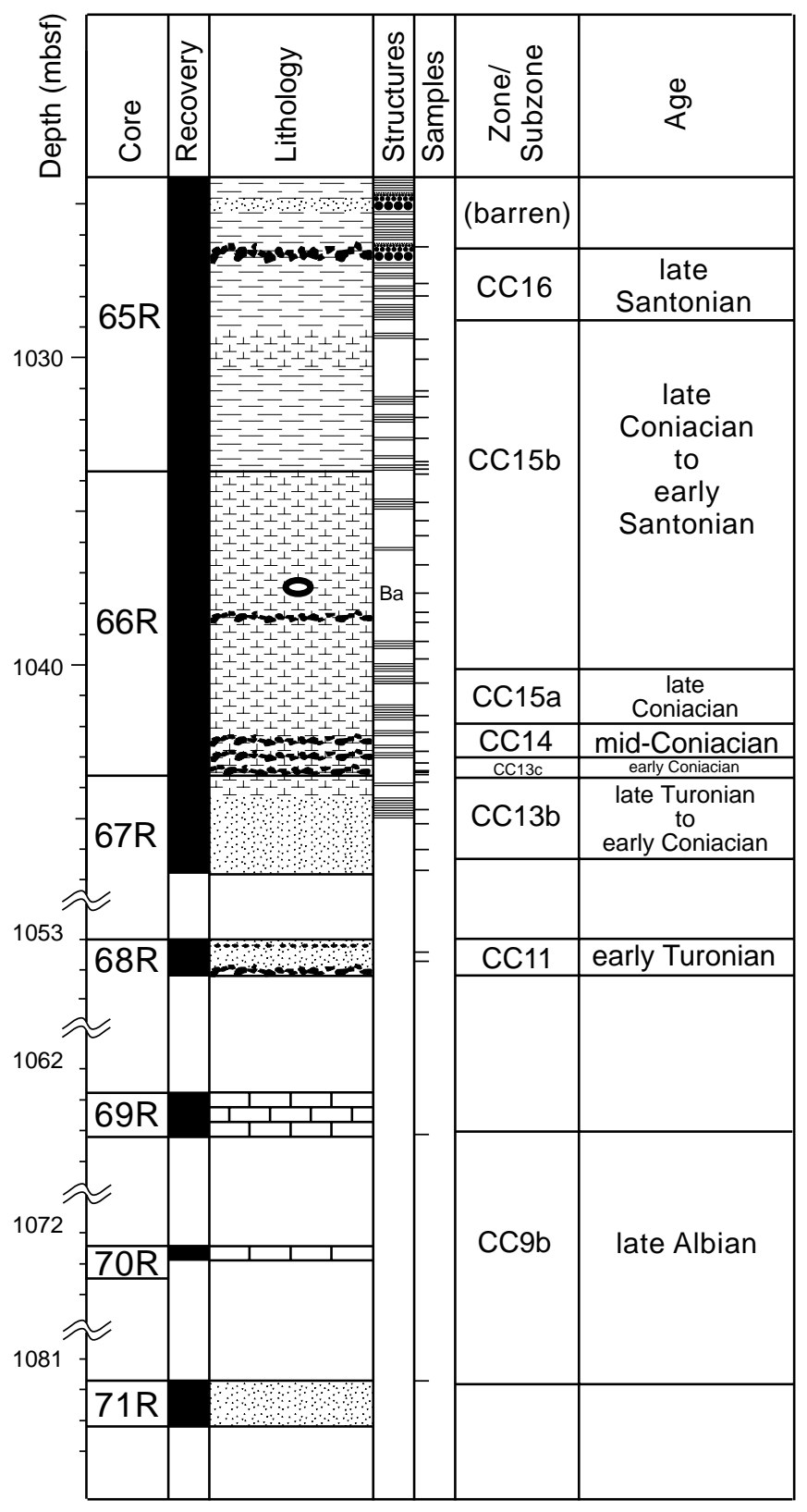

Figure 3. Biostratigraphy and lithostratigraphy of the calcareous Cretaceous sediments at Site 959. Lithology and structure patterns are from the "Explanatory Notes" chapter of the 159 Initial Reports volume (1996).

Subzone CC12b. This assignment places these samples in the upper Turonian. Samples from Sections 960C-26X-1 and 26X-2 (343-346 mbsf) contain the more advanced Marthasterites furcatus but lack Liliasterites and Micula spp. This indicates Subzone CC13b of early Coniacian age.

No specific age information is available from the interval from approximately 200 to $340 \mathrm{mbsf}$ at Site 960 . The juxtaposition of this barren sequence between sediments of Subzone CC13b and Zone CC14 (as described below) suggests it spans the CC13/CC14 zonal boundary. Section 960C-23X-CC (198.8-199.0 mbsf) consists of a thin phosphatic skeletal grainstone with rare, poorly preserved calcareous nannofossil assemblages. These assemblages include Marthasterites furcatus and Micula decussata without Lithastrinus grillii or Micula concava. This association indicates Zone CC14 of middle Coniacian age. This interval is presumably overlain by a thin $(<1$ $\mathrm{cm}$ ), hard, phosphatic hardground crust containing abundant fish debris and phosphatic pellets. This horizon was recovered at the very base of the core catcher in Core 159-960A-20R, suggesting that its original depth was approximately $184 \mathrm{mbsf}$. This crust contains rare, poorly preserved calcareous nannofossil assemblages that include Lithastrinus grillii, Lithastrinus septenarius, Micula concava, and Reinhardtites anthophorus, an association diagnostic for Subzone CC15a of late Coniacian age. In Hole 960A, this crust is disconformably overlain by palygorskitic claystone of early Eocene age.

\section{Site 962}

The Cretaceous sequence at Site 962 was penetrated twice. Hole $962 \mathrm{~B}$ was cored approximately $26 \mathrm{~m}$ of the sequence before poor recovery forced abandonment of this APC hole. Approximately $320 \mathrm{~m}$ of the Cretaceous sequence in Hole 962D was rotary cored. Much of the upper $80 \mathrm{~m}$ consists of porcellanite and calcite-cemented quartz sandstone. Below this, the Cretaceous section consists of interbedded claystone, siltstone, and quartz sandstone with significant structural deformation evident.

Much of the Cretaceous sequence in Hole 962B is barren of calcareous nannofossils. Radiolarians indicate ages of Coniacian to Santonian for interval 159-962B-8H-4, 2-28 cm, late Cenomanian for interval 159-962B-8H-4, $85 \mathrm{~cm}$ through $8 \mathrm{H}-\mathrm{CC}$, and late Albian for Core 159-962B-9H (Erbacher, Chap. 29, this volume). Samples from Core 159-962B-10H (83.5-84 mbsf) contain abundant, moderately preserved calcareous nannofossil assemblages in a highly drilling disturbed pyrite-bearing nannofossil claystone. These assemblages include abundant Watznaueria barnesae; common Biscutum constans, Glaukolithus theta, and Percivilia hauxtonensis; frequent Axopodorhabdus albianus, Gartnerago obliquum, and Tranolithus exiguus; and rare Eiffellithus collis, Ellipsogelasphaera britannica, Prediscosphaera avitus, and Prediscosphaera columnata. A single specimen of Corollithion kennedyi was observed in Sample 159962B-10H-CC. This assemblage is diagnostic for Subzone CC9c of early Cenomanian age.

The interval from Core 159-962D-3R to 37R (94.4-393.5 mbsf) consists of a sequence of tectonically disturbed, turbidity current deposits including porcellanite, calcite-cemented sandstone, dolomitic siltstone, and nannofossil claystone. Although the drilled thickness of this sequence is approximately $300 \mathrm{~m}$, it is clear that significantly less stratigraphic thickness is represented by these cores. This is exemplified by Section 159-962D-12R-4, where the entire section follows a single set of bedding planes, so that only about $10 \mathrm{~cm}$ of stratigraphic thickness (repeatedly) was recovered (Mascle, Lohmann, Clift, et al., 1996, p. 566). Nannofossil preservation throughout this sequence from Core 159-962D-3R through 37R varies widely but seems to contain the same basic assemblage (Table 2). In the best preserved material (e.g., Sample 159-962D-9R-1, 61-62 cm), the assemblage consists of abundant Glaukolithus diplogrammus, Watznaueria barnesae, and Zeugrhabdotus elegans; common Biscutum constans, Biscutum salebrosum, Corollithion signum, Tranolithus exiguus, and Zeugrhabdotus sp. cf. Z. erectus; few Eiffellithus turriseiffelii, Gartnerago nanum, and Percivilia hauxtonensis; and rare Axopodorhabdus albianus. This assemblage, in the absence of Corollithion kennedyi and Hayesites albiensis, indicates Subzone CC9b of late Albian to earliest Cenomanian age.

\section{DISCUSSION}

The oldest calcareous nannofossil assemblages recovered on Leg 159 are Albian sediments from Sites 959 and 962 . Both sites have hemipelagic sequences of Subzone CC9b of late Albian to early Cen- 
Table 2. Albian to Cenomanian calcareous nannofossils from ODP Site 962

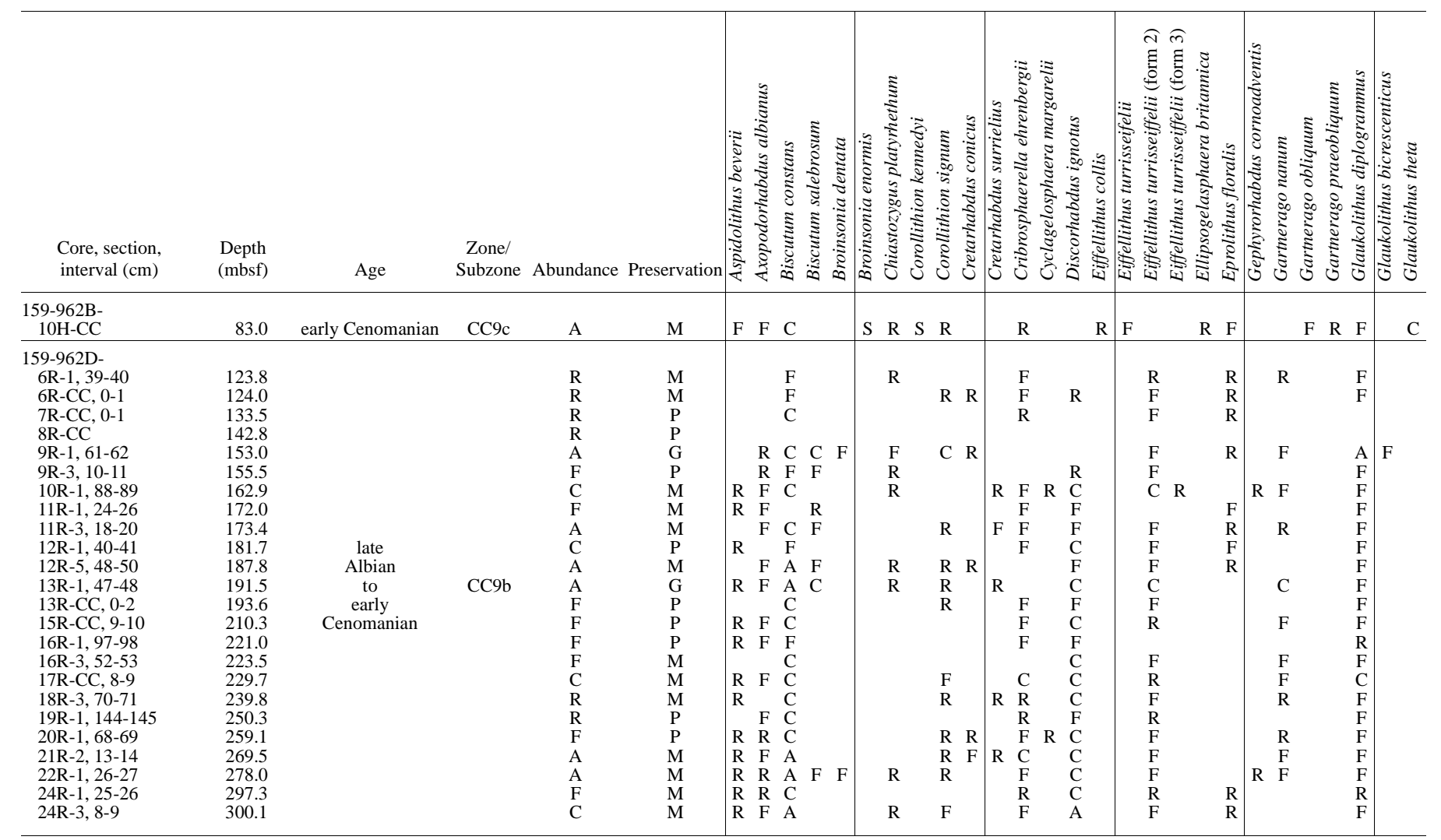

Note: Abbreviations: see Table 1 
Table 2 (continued).

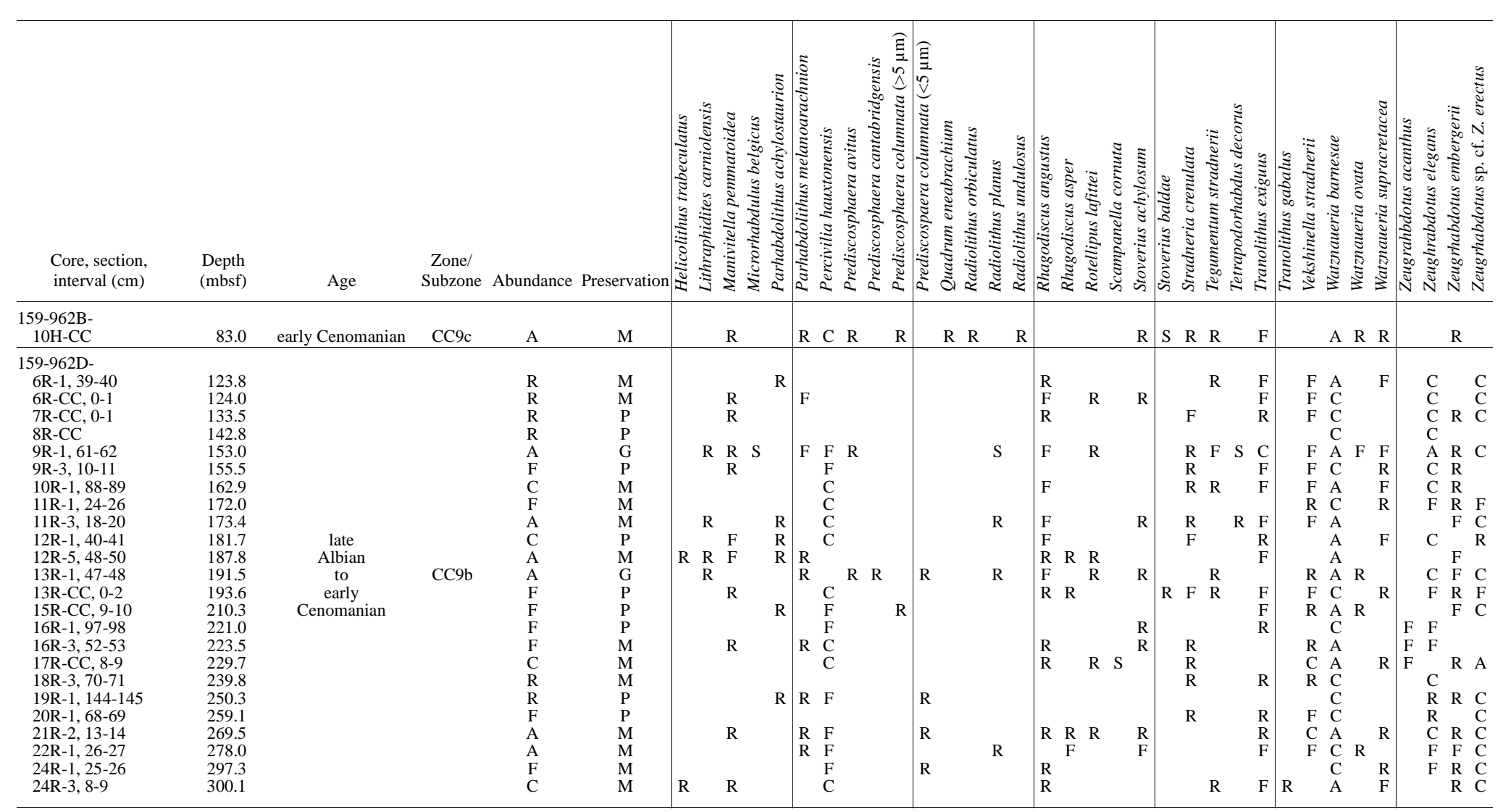


omanian age. Nannofossil-bearing hemipelagic sedimentary rocks of this age at Site 959 consist of a relatively thin (approximately $20 \mathrm{~m}$ maximum thickness) sequence of shallow-water carbonate grainstone and packstone with minor intercalations of nannofossil-bearing calcareous wackestone. At Site 962, this subzone is represented by a thick (approximately 300-m minimum thickness) sequence of calcareous clastic sedimentary rocks that have been tectonically folded and faulted. Although the section at Site 962 undoubtedly has been artificially thickened by tectonism, it is improbable that the thickening was fifteenfold. Thus, it seems likely that the section at Site 962 is significantly thicker than the coeval one at Site 959. More importantly, there is an obvious lithologic difference between these two sites, with Site 959 dominated by displaced neritic components and Site 962 dominated by clastic sedimentation.

Notable in these assemblages are the high relative abundances of Biscutum spp. and the zeugrhabdotids. Specimens of Biscutum constans and B. salebrosum collectively are the most abundant component of many of these assemblages. Previous studies have indicated the strong affinity of Biscutum spp. for areas of elevated surface water fertility during the mid-Cretaceous (Roth and Bowdler, 1981; Roth, 1986, Erba et al., 1992; Premoli Silva et al., 1989; Watkins, 1989). Similarly, the bridge zygodiscids (including Zeugrhabdotus) exhibited a strong affinity for high surface water fertility during this part of the Cretaceous (Roth and Bowdler, 1981; Roth, 1986; Watkins, 1989). The high proportion of these taxa in well-preserved samples from the section at Site 962 suggests a high level of surface water fertility during the late Albian to early Cenomanian (Subzone CC9b) in this area.

The relationship between the underlying Subzone CC9b sediment and the overlying Subzone CC9c is impossible to define precisely because of the poor recovery in this interval in both Holes 962B and 962D. For the most part, only isolated pieces of porcellanite and chert were recovered, with the exception of the approximately $40 \mathrm{~cm}$ of nannofossil claystone in Core 159-962B-10H. The small amount of lower Cenomanian (CC9c) material recovered makes it risky to generalize about surface water conditions during that time. Given that, the relatively high abundance of Biscutum constans (Table 2) suggests that surface waters may have had elevated nutrient contents. However, the notable lack of Zeugrhabdotus suggests lower fertility than in Subzone CC9b.

Nannofossils and other carbonate grains disappear from the sequence upward from Core 159-962B-10H through 9H. The overlying sequence (Section 159-962B-8H-4 through Core 9H) of radiolarianbearing claystone and porcellanite was deposited below the Carbonate Compensation Depth (CCD) during the early Late Cretaceous. Sediment accumulation rates for this interval based on radiolarian age determinations of Erbacher (Chap. 29, this volume) were low (1$2 \mathrm{~m} / \mathrm{m} . \mathrm{y}$.), reflecting sediment-starved conditions at Site 962.

The middle and upper Cenomanian is missing at Site 959, where lower Turonian sandy limestone with phosphate hardgrounds and pebbles overlie upper Albian to lower Cenomanian detrital limestones. The lower unit exhibits significant indications of transpressional tectonic deformation.

The Turonian through lower Santonian differ significantly between Sites 959 and 960 despite their geographic proximity. This sequence at Site 959 consists of less than $30 \mathrm{~m}$ of fine-grained hemipelagic sandy limestone and nannofossil claystone. The Site 959 sequence contains common phosphatic debris, including at least seven distinct hardgrounds or hardground-derived pebble beds. As a unit, this sequence accumulated at approximately $6 \mathrm{~m} / \mathrm{m}$.y. Much of this interval (at least $14 \mathrm{~m}$ ), however, is in Subzone CC15b. If this subzone is eliminated from consideration, the remaining lower Turonian to lower Santonian section is quite condensed (accumulation rate approximately $2.5 \mathrm{~m} / \mathrm{m} . \mathrm{y}$.). At nearby Site 960 , on the other hand, the correlative Turonian though Coniacian section is more than 10 times thicker (approximately $160 \mathrm{~m}$ ) than the condensed interval at Site
959. The sediment at Site 960 is significantly coarser in texture (grainstones and packstones), and contains large neritic invertebrate skeletal debris. Clearly, Site 960 was the depocenter for transported periplatform material from a nearby carbonate shelf while Site 959 (located less than $3 \mathrm{nmi}$ downslope) was sediment starved.

The evidence suggests that the oligotrophic surface waters necessary for the prosperous growth of a carbonate platform extended out into the pelagic realm over Sites 959 and 960. Turonian through Santonian calcareous nannofossil assemblages from both sites are characterized by low relative abundances of the larger Zeugrhabdotus spp. and the virtual absence of Biscutum constans and the tiny Zeugrhabdotus sp. cf. Z. erectus (Table 1). The paucity of these indicator taxa, coupled with the relatively high species richness (up to 45 species in the best preserved samples), strongly suggests low surface water nutrient levels during this time. The complete absence of preserved pelagic carbonate above the terminal hardgrounds (Samples 159-959D-65R-2, $45 \mathrm{~cm}$, and 960B-20X-CC) at both sites suggests that pelagic carbonate production (and therefore surface water fertility) may have decreased even further during the late Santonian through the rest of the Cretaceous. The complete lack of any sediment accumulation from the Santonian through Maastrictian at Site 960 may be due also, in part, to the topographically exposed nature of this site on the Marginal Ridge.

\section{CONCLUSIONS}

The initial invasion of the Deep Ivorian Basin by calcareous nannoplankton occurred during the late Albian. These eldest nannoplankton lived in surface waters of moderate to warm temperatures with relatively high fertility. Hemipelagic sedimentation occurred through the late Albian to early Cenomanian in the Deep Ivorian Basin (Site 959), while clastic turbidites accumulated at the deeper Site 962 (marginal to the Deep Ivorian Basin proper). These sediments were tectonically disturbed sometime during the Cenomanian, although the precise dating of this tectonism cannot be determined from calcareous nannofossil biostratigraphy alone. It is also about this time that Site 962 dropped below the local CCD, where it was to remain until the Pliocene.

Following the Cenomanian tectonism, a significant decrease in surface water fertility in the area resulted in low rates of pelagic sediment accumulation at all three sites. This reduction was hardly noticeable at Site 960, where large quantities of displaced neritic carbonate debris accumulated during the Turonian through Coniacian. This shallow-water carbonate material did not reach the nearby Site 959, where only a thin, condensed sequence of nannofossil claystones and phosphate hardgrounds accumulated during the Turonian through late Santonian.

Continued, or even enhanced, nutrient depletion of the surface waters may have led, at least in part, to the cessation of sediment accumulation at Sites 960 and 962 during the Santonian through Maastrichtian. The topographically exposed nature of Site 960 and, to a lesser extent, 962, may have contributed to the disconformities that characterize the Santonian to Maastrichtian record at these sites.

\section{ACKNOWLEDGMENTS}

We wish to thank Captain Ed Oonk and the entire crew of the SEDCO/BP471 for their help in providing a comfortable voyage. Our special thanks are extended to Mr. Wayne Malone and the drilling crew, whose expertise and dedication provided us with the material for this study. We thank our scientific colleagues for their stimulating discussion on land and at sea. The manuscript was reviewed by Timothy J. Bralower and Sherwood W. Wise, Jr. Their comments significantly improved the final product. We also thank the editorial 
staff at ODP, who showed us the error of our ways. Maija E. Schellpeper and Denise Kulhanek helped greatly in manuscript preparation. Funding for this study was provided to DKW by JOI/USSAC.

\section{REFERENCES}

Bralower, T.J., 1988. Calcareous nannofossil biostratigraphy and assemblages of the Cenomanian/Turonian boundary interval: implications for the origin and timing of oceanic anoxia. Paleoceanography, 8:275-316.

Erba, E., Castradori, D., Guasti, G., and Ripepe, M., 1992. Calcareous nannofossils and Milankovitch cycles: the example of the Albian Gault Clay Formation (southern England). Palaeogeogr., Palaeoclimatol., Palaeoecol., 93:47-69.

Loeblich, A.R., Jr., and Tappan, H., 1966. Annotated index and bibliography of the calcareous nannoplankton, I. Phycologia, 5:81-216.

, 1968. Annotated index and bibliography of the calcareous nannoplankton, II. J. Paleontol., 42:584-598.

, 1969. Annotated index and bibliography of the calcareous nannoplankton, III. J. Paleontol., 43:568-588.

, 1970a. Annotated index and bibliography of the calcareous nannoplankton, IV. J. Paleontol., 44:558-574.

, 1970b. Annotated index and bibliography of the calcareous nannoplankton, V. Phycologia, 9:157-174.

1971. Annotated index and bibliography of the calcareous nannoplankton, VI. Phycologia, 10:315-339.

, 1973. Annotated index and bibliography of the calcareous nannoplankton, VII. J. Paleontol., 47:715-759.

Mascle, J., Lohmann, G.P., Clift, P.D., et al., 1996. Proc. ODP, Init. Repts., 159: College Station, TX (Ocean Drilling Program).

Perch-Nielsen, K., 1985. Mesozoic calcareous nannofossils. In Bolli, H.M., Saunders, J.B., and Perch-Nielsen, K. (Eds.), Plankton Stratigraphy: Cambridge (Cambridge Univ. Press), 329-426.

Premoli Silva, I., Erba, E., and Tornaghi, M.E., 1989. Paleoenvironmental signals and changes in surface fertility in Mid Cretaceous Corg-rich pelagic facies of the Fucoid Marls (Central Italy). Terra Nova, 1:443448

Roth, P.H., 1986. Mesozoic palaeoceanography of the North Atlantic and Tethys oceans. In Summerhayes, C.P., and Shackleton, N.J. (Eds.), North Atlantic Palaeoceanography. Geol. Soc. Spec. Publ. London, 21:299320

Roth, P.H., and Bowdler, J., 1981. Middle Cretaceous calcareous nannoplankton biogeography and oceanography of the Atlantic Ocean. In Warme, J.E., Douglas, R.G., and Winterer, E.L. (Eds.), The Deep Sea Drilling Project: a Decade of Progress. Spec. Publ.-Soc. Econ. Paleontol. Mineral., 32:517-546.

Shipboard Scientific Party, 1996. Explanatory Notes. In Mascle, J., Lohmann, G.P., Clift, P.D., et al., Proc. ODP, Init. Repts., 159: College Station, TX (Ocean Drilling Program), 17-46.

Sissingh, W., 1977. Biostratigraphy of Cretaceous calcareous nannoplankton. Geol. Mijnbouw, 56:37-65.

Steinmetz, J.C., 1984a. Bibliography and taxa of calcareous nannoplankton-III. INA Newsl., 6:6-37.

, 1984b. Bibliography and taxa of calcareous nannoplankton-IV. INA Newsl., 6:55-61.

1985a. Bibliography and taxa of calcareous nannoplankton-V. INA Newsl., 7:5-28.

, 1985b. Bibliography and taxa of calcareous nannoplankton-VI. INA Newsl., 7:122-145.

, 1986. Bibliography and taxa of calcareous nannoplankton-VIII. INA Newsl., 8:66-87.

, 1987a. Bibliography and taxa of calcareous nannoplankton-IX. INA Newsl., 9:8-29.

, 1987b. Bibliography and taxa of calcareous nannoplankton-X. INA Newsl., 10:81-109.

, 1988a. Bibliography and taxa of calcareous nannoplankton-XI. INA Newsl., 10:7-28.

, 1988b. Bibliography and taxa of calcareous nannoplankton-XII. INA Newsl., 10:60-88.

1989. Bibliography and taxa of calcareous nannoplankton-XIII. INA Newsl., 11:6-23.

Stradner, H., and Steinmetz, J., 1984. Cretaceous calcareous nannofossils from the Angola Basin, Deep Sea Drilling Project Site 530. In Hay,
W.W., Sibuet, J.-C., et al., Init. Repts. DSDP, 75: Washington (U.S. Govt. Printing Office), 565-649.

van Heck, S.E., 1979a. Bibliography and taxa of calcareous nannoplankton. INA Newsl., 1:AB1-B27.

1979b. Bibliography and taxa of calcareous nannoplankton. INA Newsl., 1:ABV1-B42.

1980a. Bibliography and taxa of calcareous nannoplankton. INA

Newsl., 2:5-34.

1980b. Bibliography and taxa of calcareous nannoplankton. INA

Newsl., 2:43-81.

1981a. Bibliography and taxa of calcareous nannoplankton. INA

Newsl., 3:4-41.

1981b. Bibliography and taxa of calcareous nannoplankton. INA

Newsl., 3:51-86.

1982a. Bibliography and taxa of calcareous nannoplankton. INA

Newsl., 4:7-50.

1982b. Bibliography and taxa of calcareous nannoplankton. INA Newsl., 4:65-96.

1983. Bibliography and taxa of calcareous nannoplankton. INA Newsl., 5:4-13.

Varol, O., 1992. Taxonomic revision of the Polycyclolithaceae and its contribution to Cretaceous biostratigraphy. Newsl. Stratigr., 27:93-127.

Watkins, D.K., 1985. Biostratigraphy and paleoecology of calcareous nannofossils in the Greenhorn marine cycle. Soc. Econ. Paleontol. Mineral. Field Trip Guidebook, 4:151-156.

, 1989. Nannoplankton productivity fluctuations and rhythmicallybedded pelagic carbonates of the Greenhorn Limestones (Upper Cretaceous). Palaeogeogr., Palaeoclimatol., Palaeoecol., 74:75-86.

\section{Date of initial receipt: 17 September 1996 \\ Date of acceptance: 6 February 1997 \\ Ms 159SR-013}

\section{APPENDIX}

Ahmuellerella octoradiata (Gorka, 1957) Reinhardt, 1964

Ahmuellerella regularis (Gorka, 1957) Verbeek, 1977

Amphizygus brooksii (Bukry, 1969)

Aspidolithus beverii (Bukry, 1969) Perch-Nielsen (1984)

Axopodorhabdus albianus (Black, 1967) Wind and Wise In Wise and Wind (1977)

Biscutum constans (Gorka, 1957) Black In Black and Barnes (1959)

Biscutum salebrosum (Black, 1971) Perch-Nielsen (1984)

Broinsonia dentata Bukry (1969)

Broinsonia enormis (Shumenko, 1968) Manivit (1971)

Chiastozygus litterarius (Gorka, 1957) Manivit (1971)

Chiastozygus platyrhethus Hill, 1976

Corollithion exiguum Stradner (1961)

Corollithion kennedyi Crux (1981)

Corollithion signum Stradner (1963)

Cretarhabdus conicus Bramlette and Martini (1964)

Cretarhabdus surrielius Thierstein (1974)

Cribrosphaerella ehrenbergii (Arkhangelsky, 1912) Deflandre (1952)

Cyclagelosphaera margarelii Noel (1965)

Discorhabdus ignotus (Gorka, 1957) Perch-Nielsen (1968)

Eifflellithus collis Hoffman (1970)

Eiffellithus eximius (Stover, 1966) Perch-Nielsen (1968)

Eiffellithus gorkae Reinhardt (1965)

Eiffellithus turriseiffelii (Deflandre, 1954) Reinhardt (1965)

Ellipsogelasphaera britannica (Stradner, 1963) Perch-Nielsen (1968)

Eprolithus eptapetalus Varol (1992)

Eprolithus floralis (Stradner, 1962) Stover (1966)

Eprolithus octopetalus Varol (1992)

Flabellites oblongata (Bukry, 1969) Crux et al. (1982)

Gartnerago diversum Thierstein (1972)

Gartnerago nanum Thierstein (1974)

Gartnerago obliquum (Stradner, 1963) Noel (1970)

Gartnerago praeobliquum

Gartnerago theta (Black, 1959) Jakubowski (1986)

Gephyrorhabdus coronadventis (Reinhardt, 1966) Hill (1976)

Glaukolithus bicrescenticus (Stover, 1966) 
Glaukolithus diplogrammus (Deflandre, 1954) Reinhardt (1964)

Helicolithus trabeculatus (Gorka, 1957) Verbeek (1977)

Kamptnerius tabulatus Perch-Nielsen (1968)

Liliasterites angularis ?vábenická and Stradner (1984) In Stradner and Steinmetz (1984)

Liliasterites atlanticus Stradner and Steinmetz (1984)

Lithraphidites carniolensis Deflandre (1963)

Lithastrinus grillii Stradner (1962)

Lithastrinus moratus Stover (1966)

Lithastrinus septenarius Forchheimer (1972)

Manivitella pemmatoidea (Deflandre, 1965) Thierstein (1971)

Marthasterites furcatus (Deflandre, 1954) Deflandre (1959)

Marthasterites jucundus Deflandre (1959)

Microstaurus ficula (Stover, 1966)

Microrhabdulus belgicus Hay and Towe (1963)

Microrhabdulus decoratus Deflandre (1959)

Micula concava (Stradner, 1960) Verbeek (1976)

Micula decussata Vekshina (1959)

Parhabdolithus achylostaurion Hill (1976)

Parhabdolithus melanoarachnion Hill (1976)

Percivillia hauxtonensis Black (1973)

Placozygus fibuliformis (Reinhardt, 1964) Hoffman (1970)

Prediscosphaera avitus (Black, 1973) Perch-Nielsen (1984)

Prediscosphaera cantabrigensis (Black, 1967)

Prediscosphaera columnata (Black, 1967) Reinhardt (1970)

Prediscosphaera cretacea (Arkhangelsky, 1912) Gartner (1968)

Prediscosphaera honjoi Bukry (1969)

Prediscosphaera intercisa (Deflandre, 1954) Shumenko (1976)

Prediscosphaera ponticula (Bukry, 1969) Perch-Nielsen (1984)

Prediscosphaera spinosa (Bramlette and Martini,1964) Gartner (1968)

Quadrum eneabrachium Varol (1992)

Quadrum eptabrachium Varol (1992)

Quadrum gartnerii Prins and Perch-Nielsen In Manivit et al. (1977)
Quadrum intermedium Varol (1992)

Radiolithus orbiculatus (Forchheimer, 1976) Varol (1992)

Radiolithus planus Stover (1966)

Radiolithus undosus (Black, 1973) Varol (1992)

Reinhardtites anthophorus (Deflandre, 1959) Perch-Nielsen (1968)

Rhagodiscus angustus (Stradner. 1963) Reinhardt (1971)

Rhagodiscus asper (Stradner, 1963) Reinhardt (1967)

Rhagodiscus splendens (Deflandre, 1953) Verbeek (1977)

Rotelapillus crenulatus (Stover, 1966) Perch-Nielsen (1984)

Rotelapillus lafitteii (Noel, 1957) Noel (1973)

Scampanella cornuta Forchheimer and Stradner (1973)

Stoverius asymmetricus (Bukry, 1969) Perch-Nielsen (1984)

Stoverius achylosus (Stover, 1966) Perch-Nielsen (1984)

Stoverius baldiae (Stradner and Adamiker, 1966) Perch-Nielsen (1984)

Stoverius biarcus (Bukry, 1969) Perch-Nielsen (1984)

Stoverius coronatus (Bukry, 1969) Perch-Nielsen (1984)

Stradneria crenulata (Bramlette and Martini,1964) Nöel (1970)

Tegumentum stradnerii Thierstein (1972)

Tetrapodorhabdus decorus (Deflandre, 1954) Wind and Wise (1983)

Tranolithus exiguus Stover (1966)

Tranolithus gabalus Stover (1966)

Tranolithus minimus (Bukry, 1969) Perch-Nielsen (1984)

Tranolithus phacelosus Stover (1966)

Vekshinella stradneri Rood, Hay, and Barnard (1971)

Watznaueria barnesae (Black, 1959) Perch-Nielsen (1968)

Watznaueria biporta Bukry (1969)

Watznaueria ovata Bukry (1969)

Watznaueria supracretacea (Reinhardt, 1965) Wise and Wind (1977)

Zeugrhabdotus acanthus Reinhardt (1965)

Zeugrhabdotus elegans (Gartner, 1968) Mutterlose (1988)

Zeugrhabdotus embergerii Noel (1959) Perch-Nielsen (1984)

Zeugrhabdotus pseudanthophorus (Bramlette and Martini, 1964) PerchNielsen (1984) 


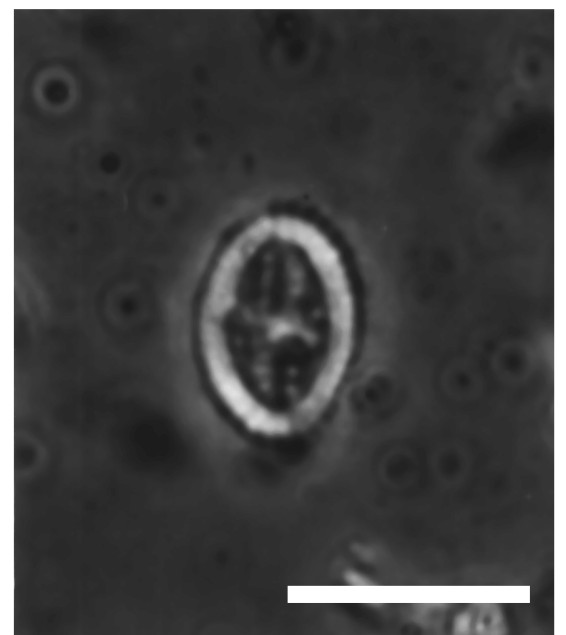

1

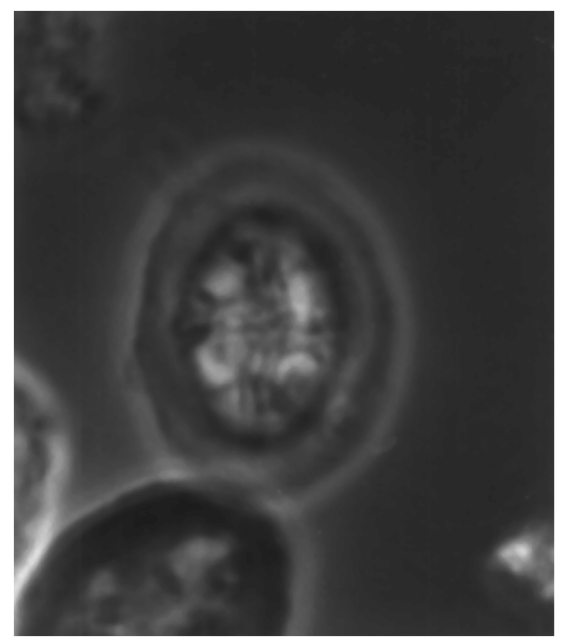

4

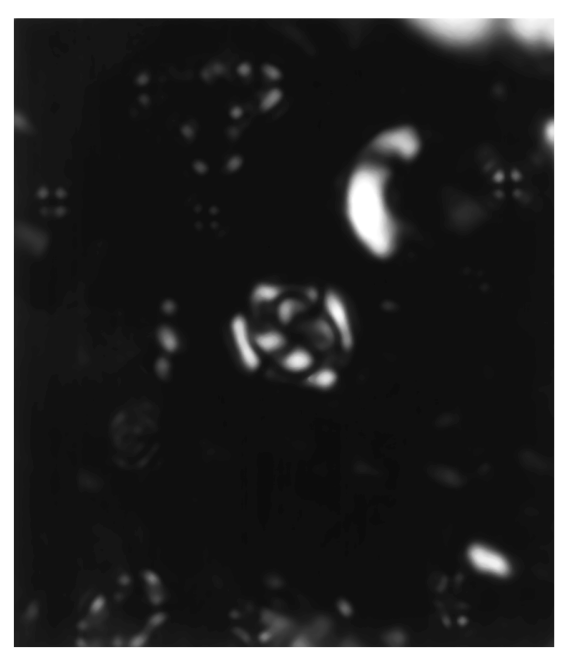

7

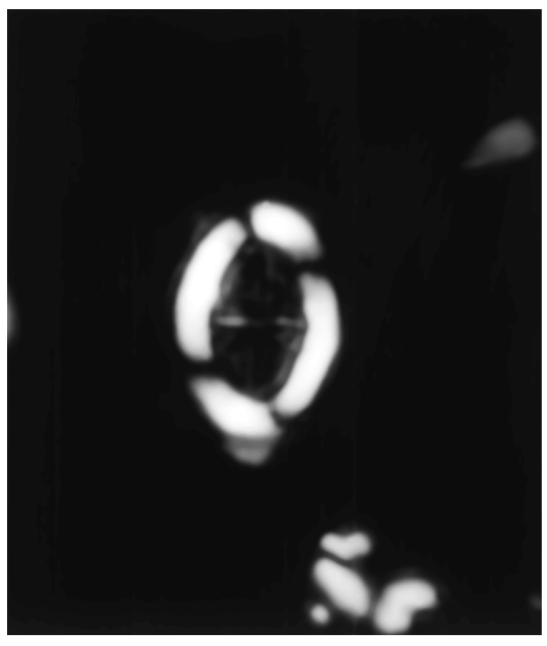

2

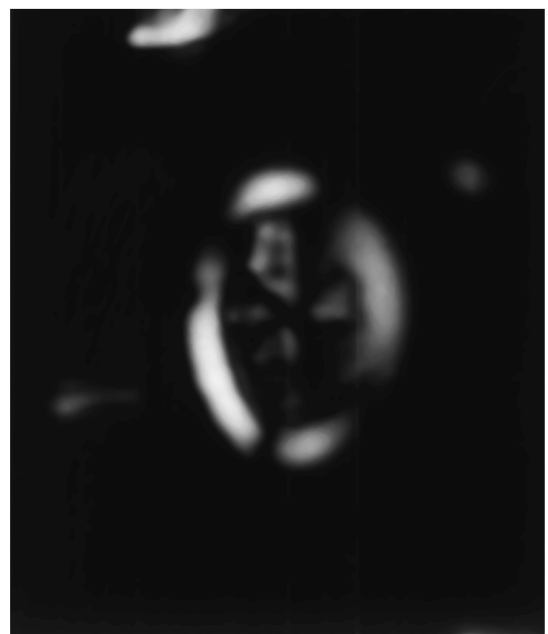

5

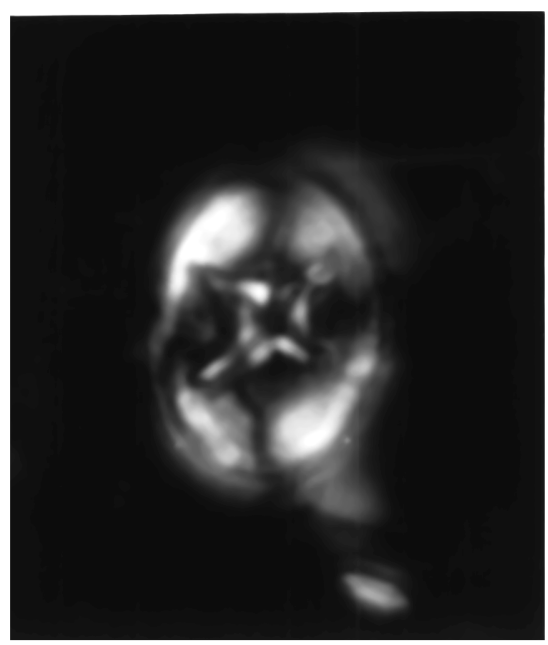

8

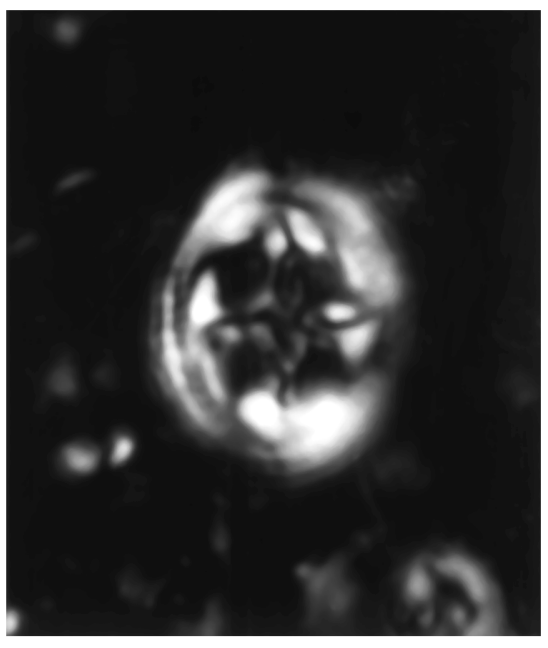

3

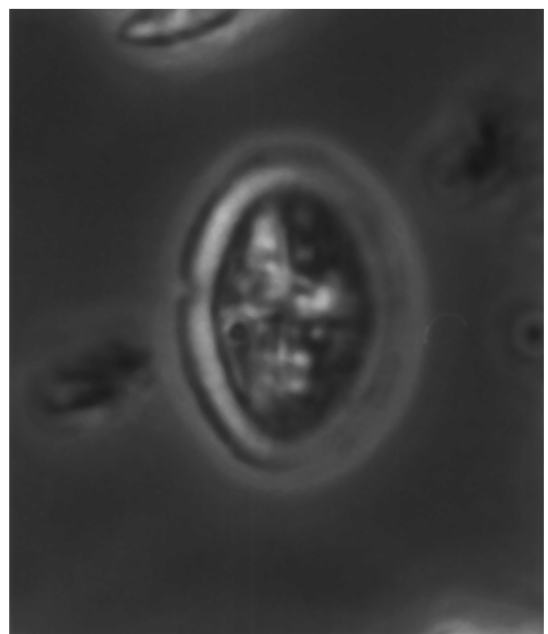

6

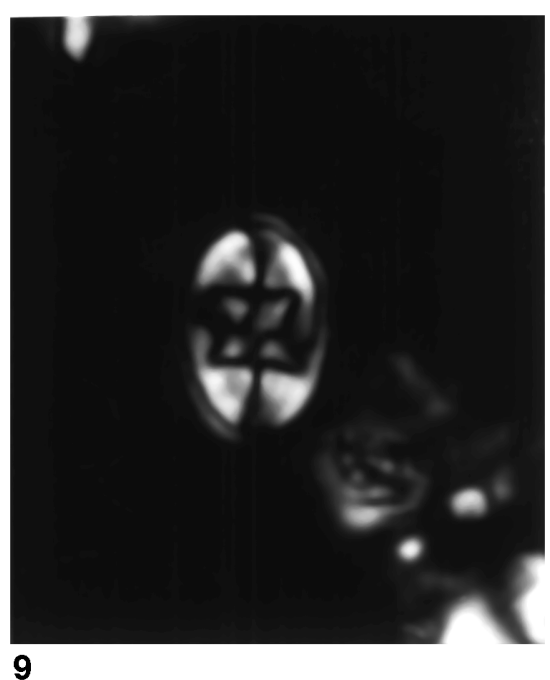

Plate 1. Bar scale $=10 \mu \mathrm{m}$. Magnification approximately 2440x. Figures 1, 2. Aspidolithus beverii, Sample 159-959D-68R-1, 14-15 cm. 3, 4. Axopodorhabdus albianus, Sample 159-962D-10R-1, 88-89 cm. 5, 6. Broinsonia enormis, Sample 159-962B-10H-CC. 7. Corollithion kennedyi, Sample 159-962B-10H-CC. 8. Eifflellithus turriseifellii, Sample 159-962D-6R-1, 39-40 cm. 9. Eiffellithus collis, Sample 159-959D-67R-2, 105-106 cm. 


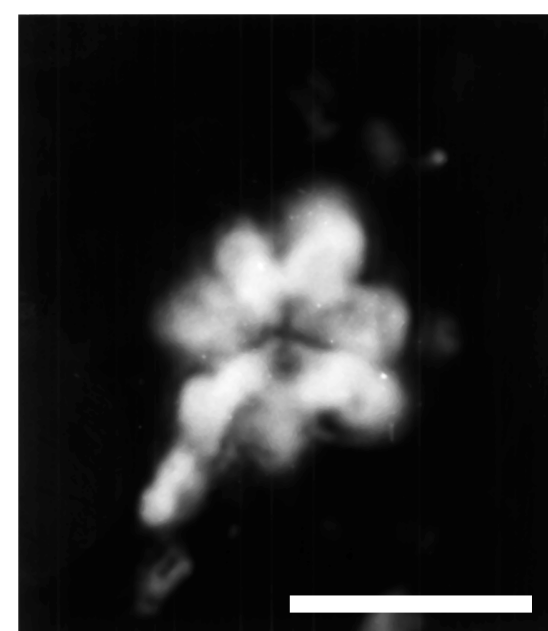

1

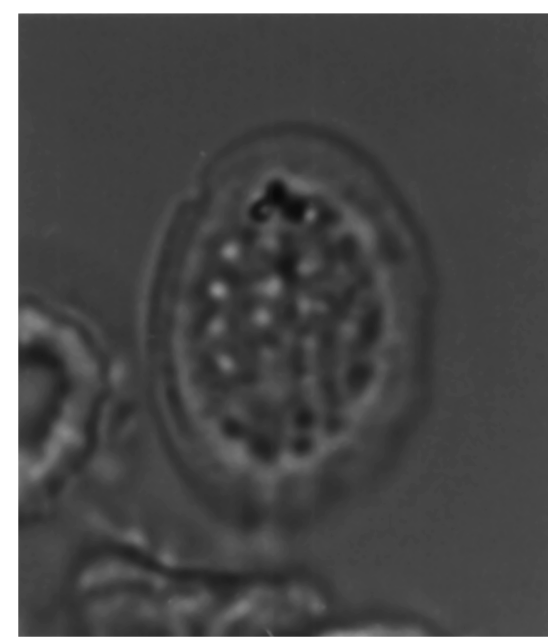

4

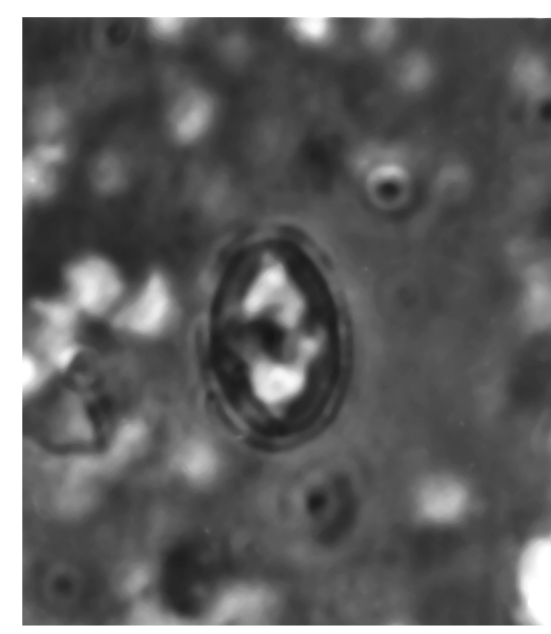

7

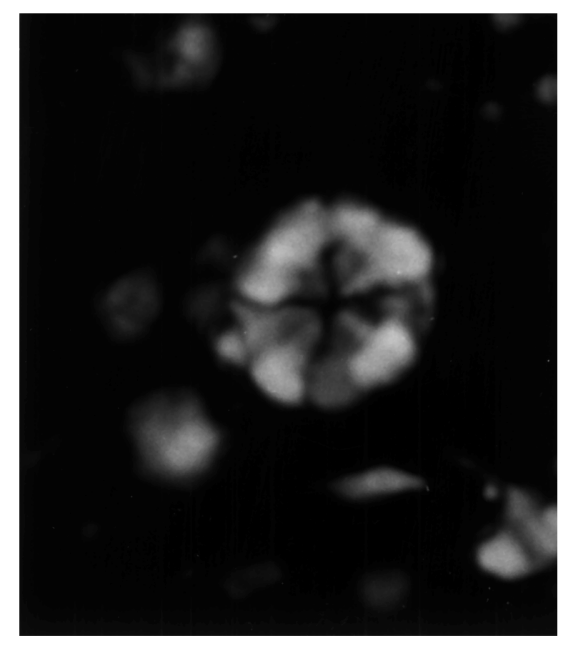

2

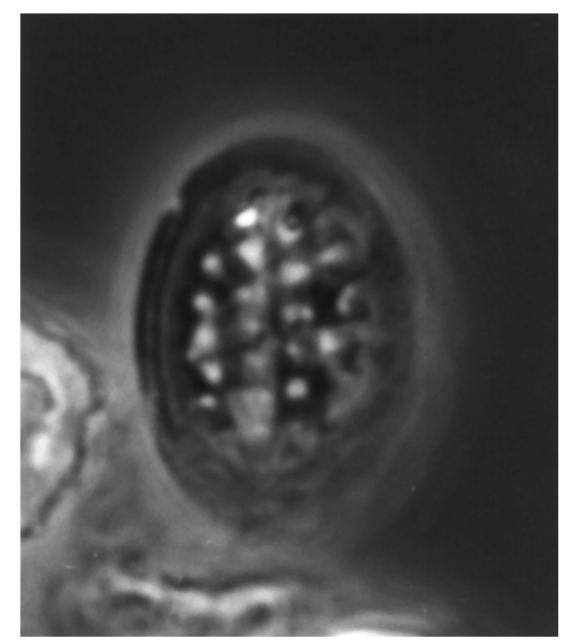

5

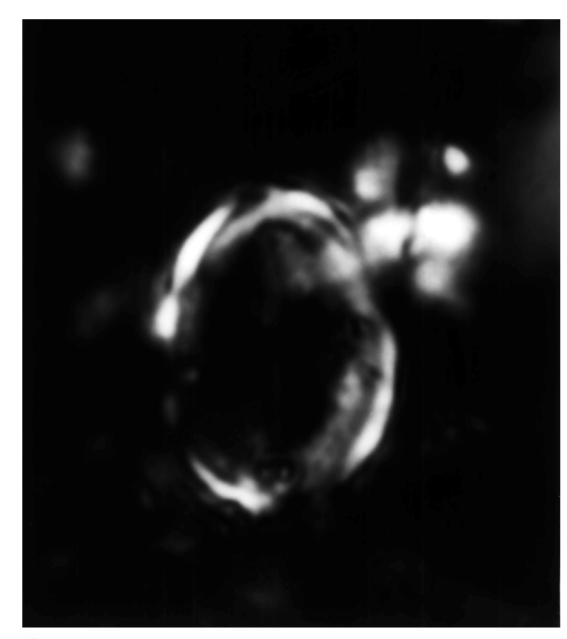

8

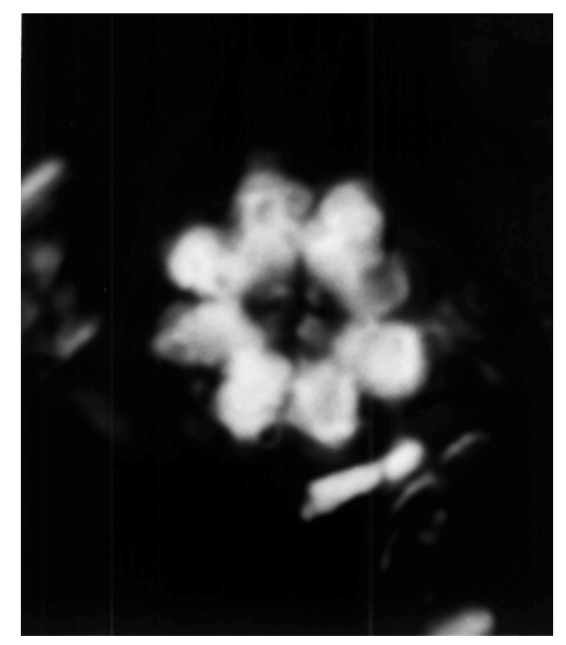

3

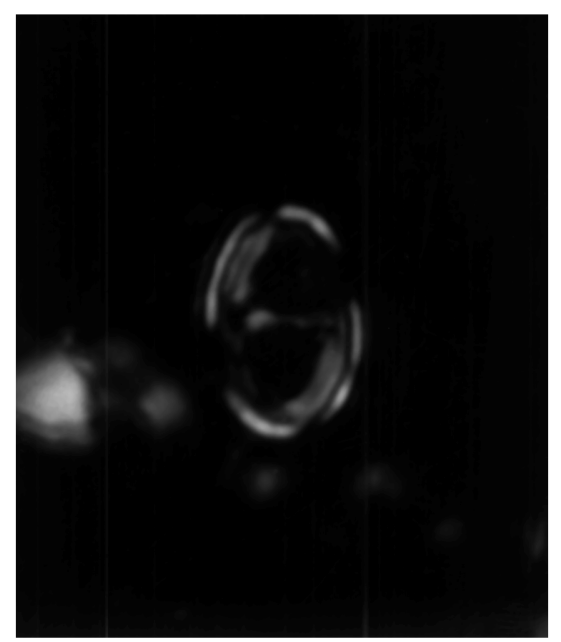

6

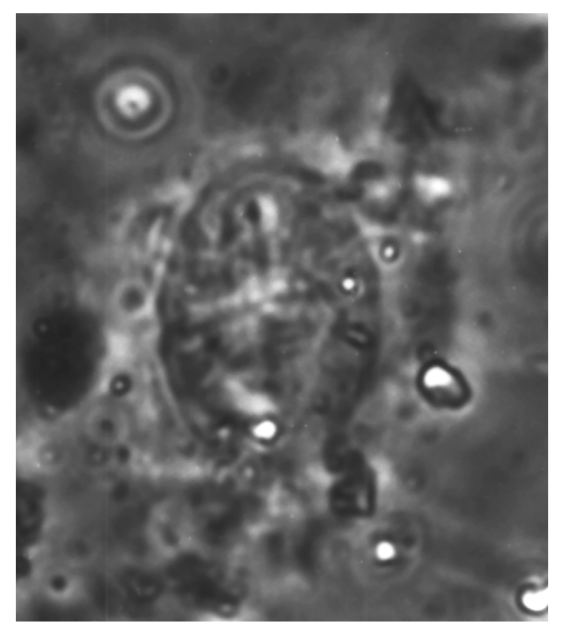

9

Plate 2. Bar scale $=10 \mu \mathrm{m}$. Magnification approximately 2440×. 1. Eprolithus eptapetalus, Sample 159-959D-68R-1, 14-15 cm. 2. Eprolithus floralis, Sample 159-962D-6R-CC, 0-1 cm. 3. Eprolithus octopetalus, Sample 159-959D-68R-1, 14-15 cm. 4, 5. Gartnerago diversum, Sample 159-959D-67R-2, 105-106 cm. 6, 7. Gartnerago nanum, Sample 159-962D-6R-1, 39-40 cm. 8, 9. Gartnerago obliquum, Sample 159-959D-67R-2, 105-106 cm. 


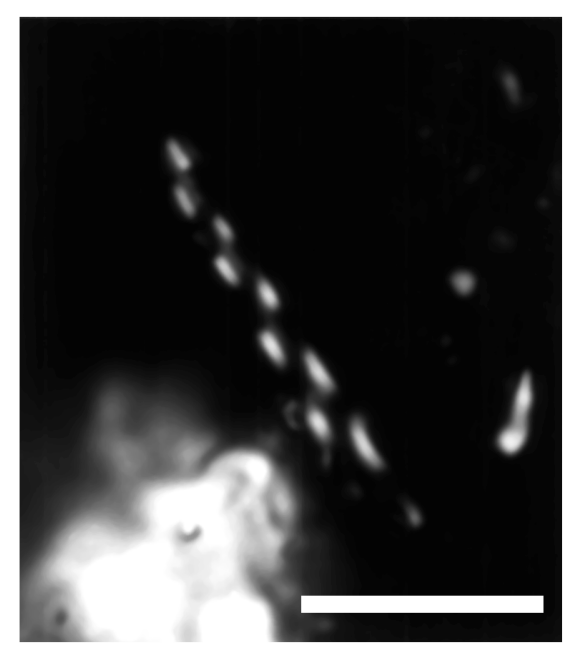

1

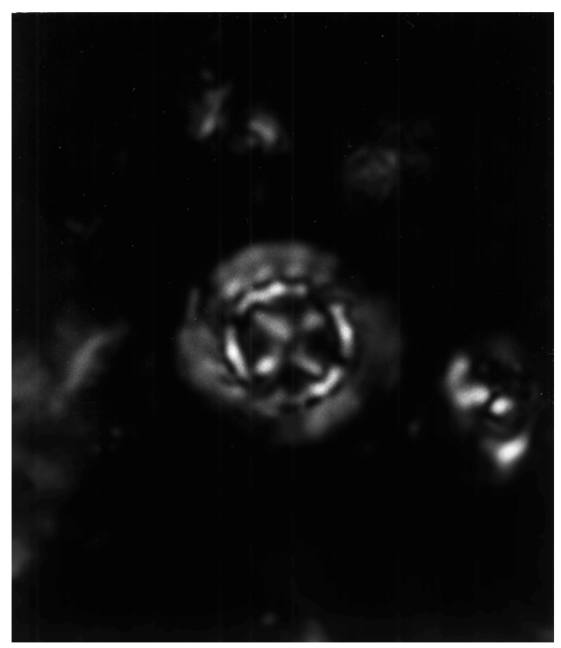

4

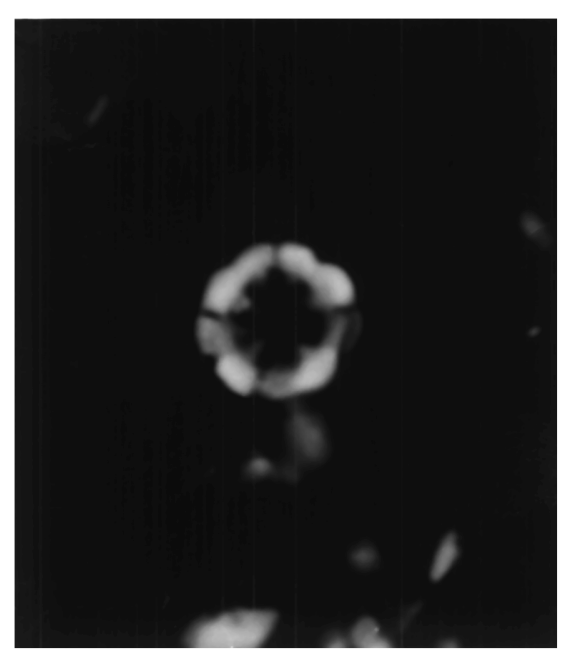

7

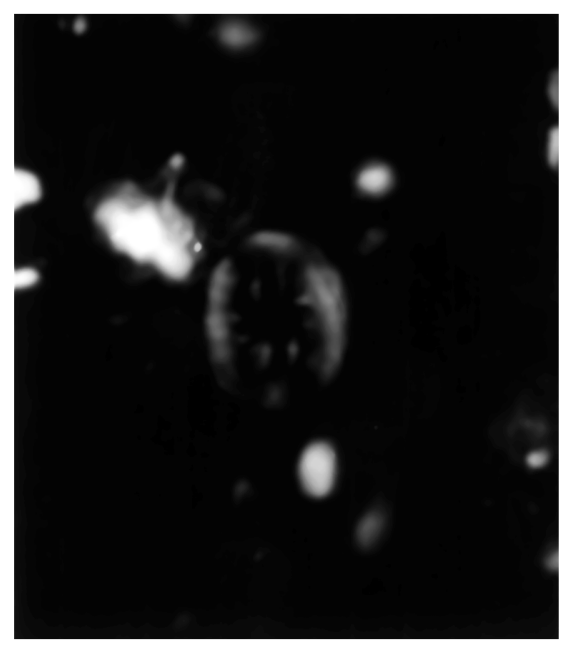

2

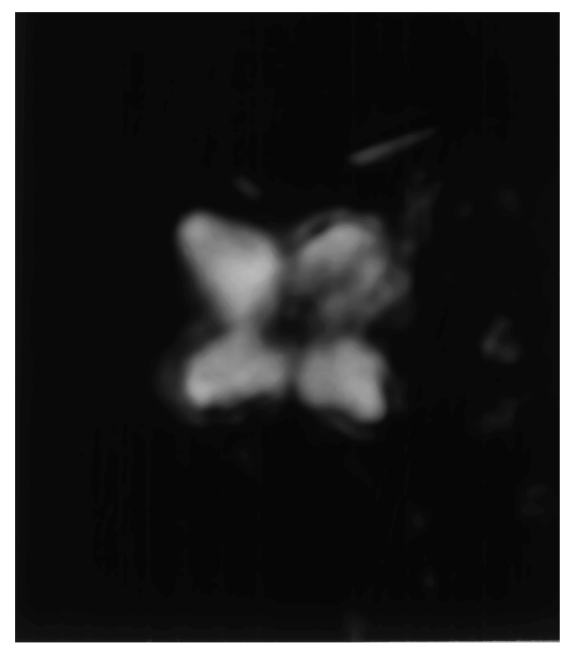

5

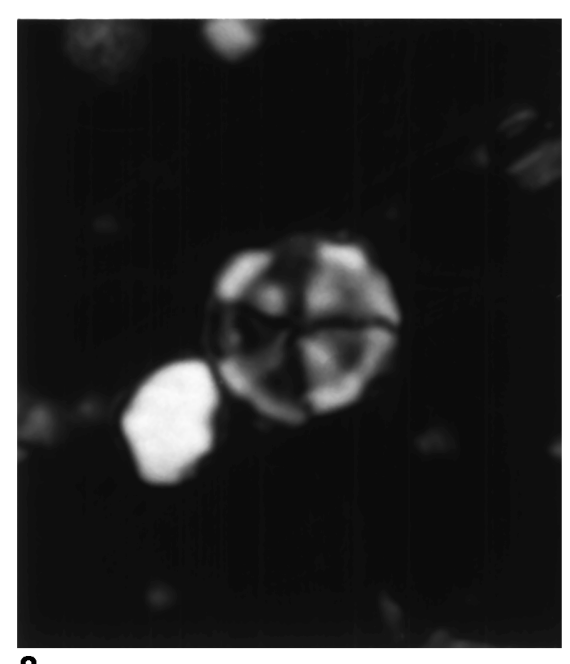

8

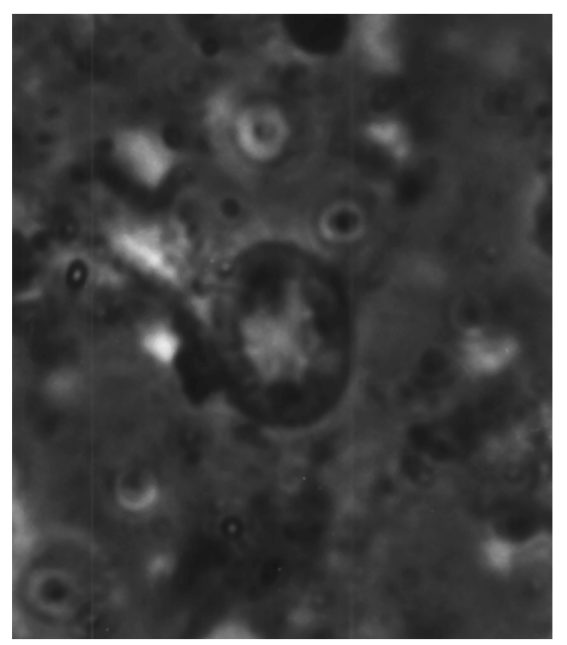

3

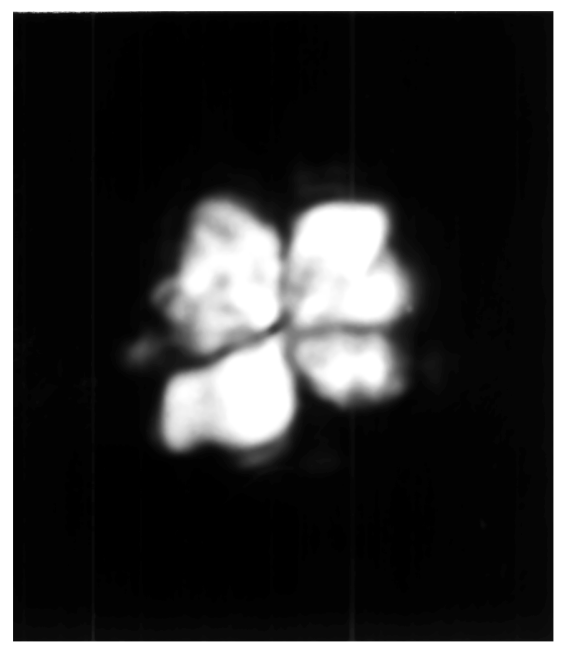

6

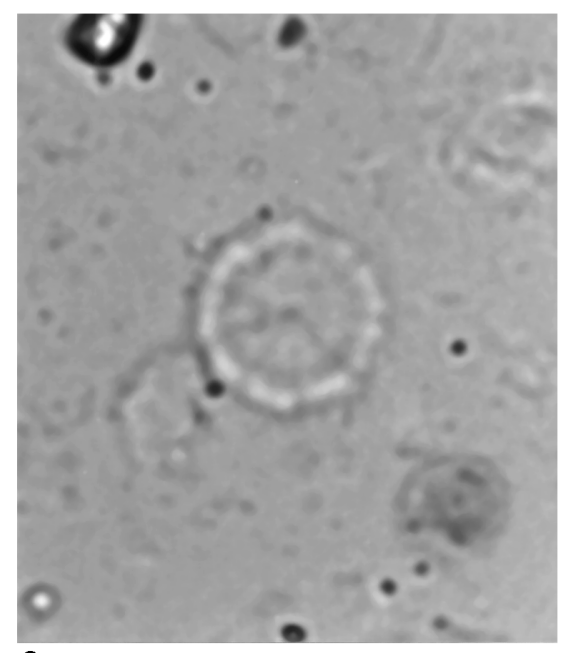

9

Plate 3. Bar scale $=10 \mu \mathrm{m}$. Magnification approximately 2440×. 1. Microrhabdulus decoratus, Sample 159-959D-66R-7, 8-11 cm. 2, 3. Parhabdolithus melanoarachnion, Sample 159-959D-68R-1, 14-15 cm. 4. Prediscosphaera avitus, Sample 159-962B-10H-CC. 5. Quadrum gartnerii, Sample 159-959D-68R-1, 63-65 cm. 6. Quadrum intermedium, Sample 159-959D-68R-1, 63-65 cm. 7. Radiolithus orbiculatus, Sample 159-959D-68R-1, 14-15 cm. 8, 9. Radiolithus planus, Sample 159-962D-22R-1, 26-27 cm. 


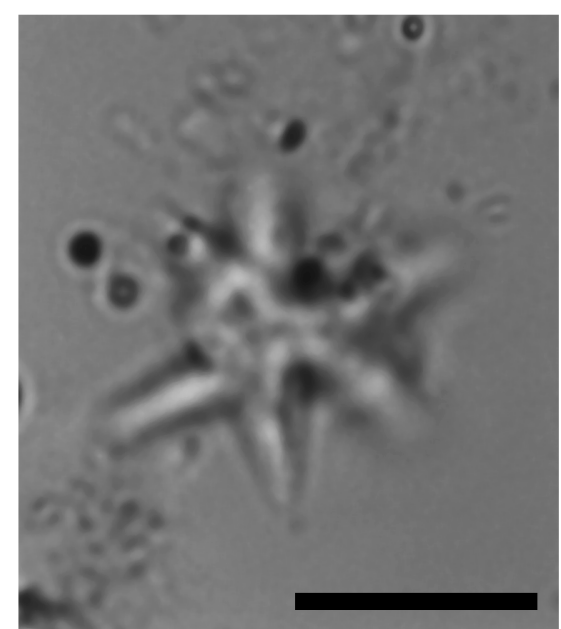

1

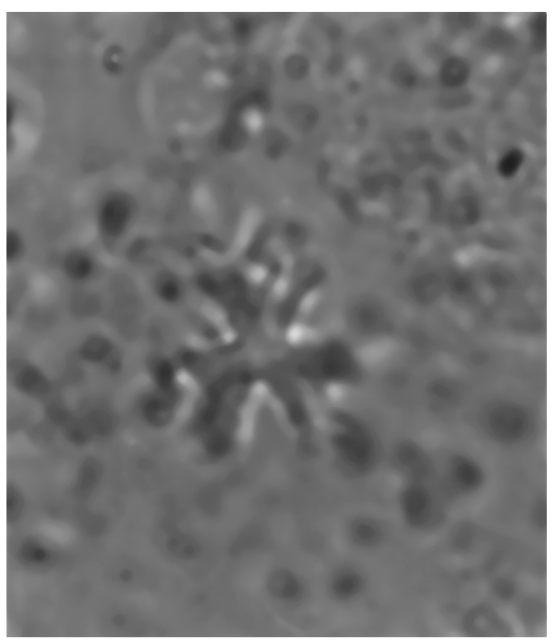

4

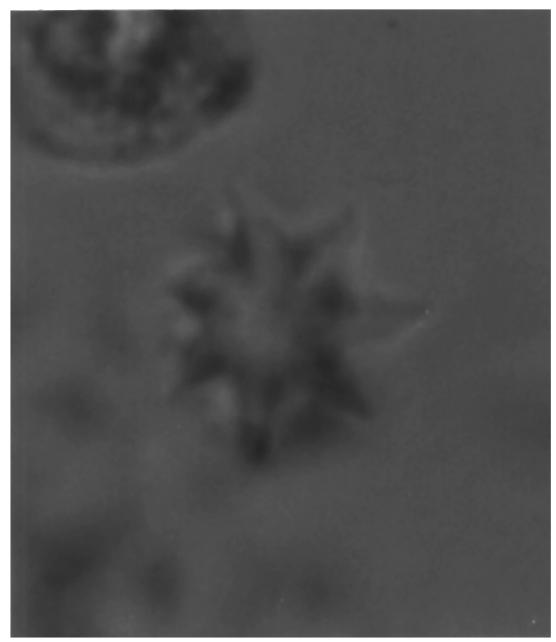

7

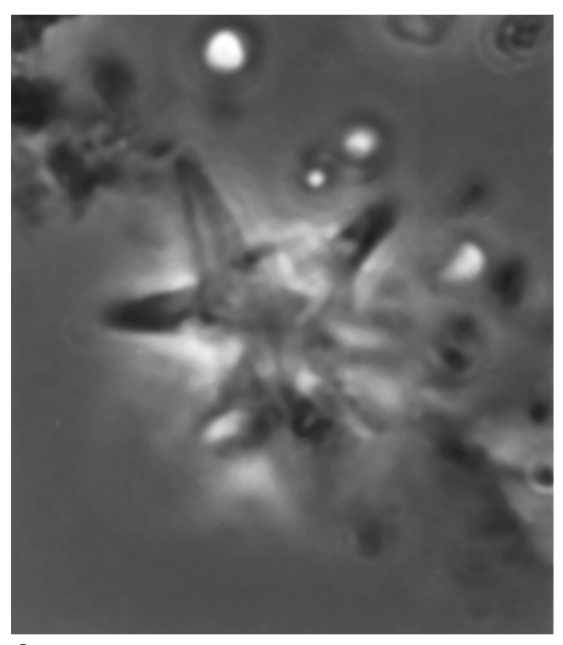

2

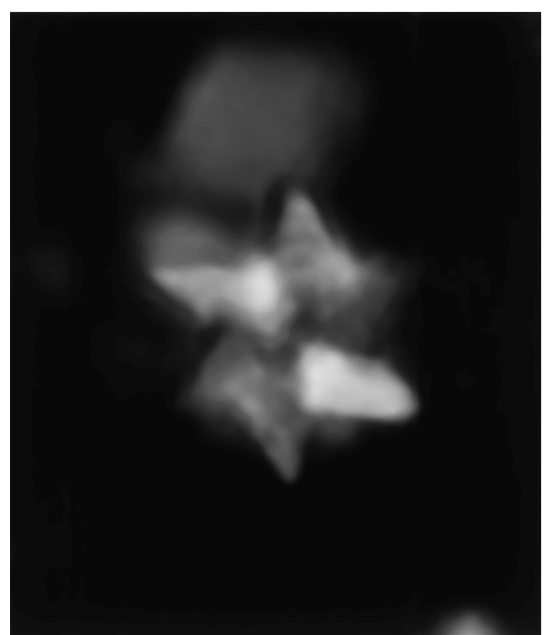

5

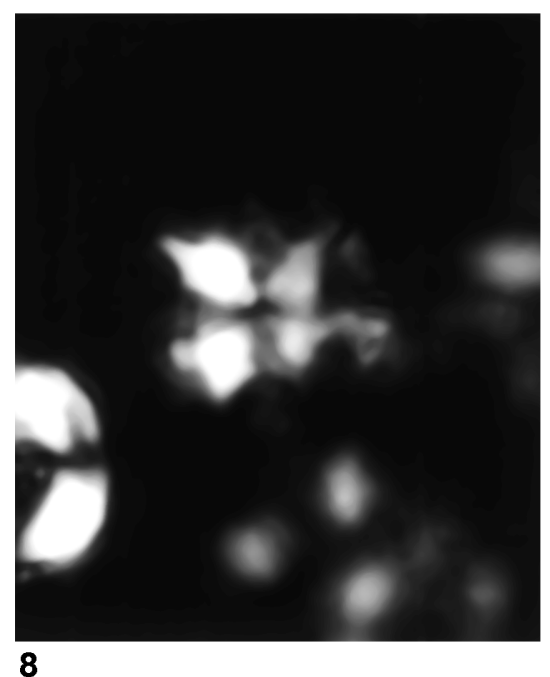

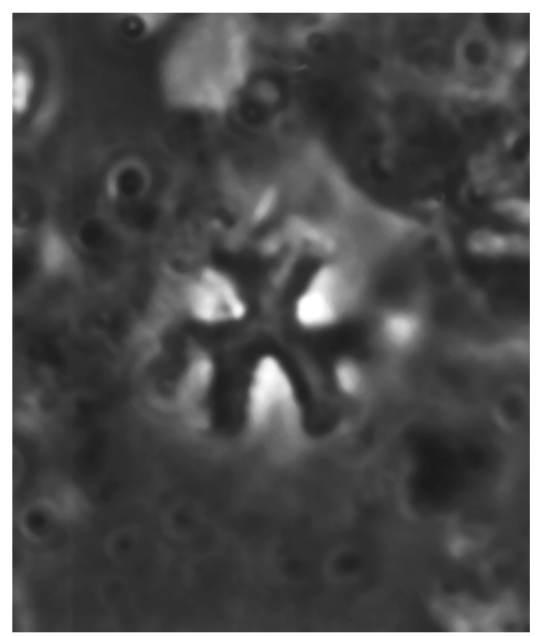

3

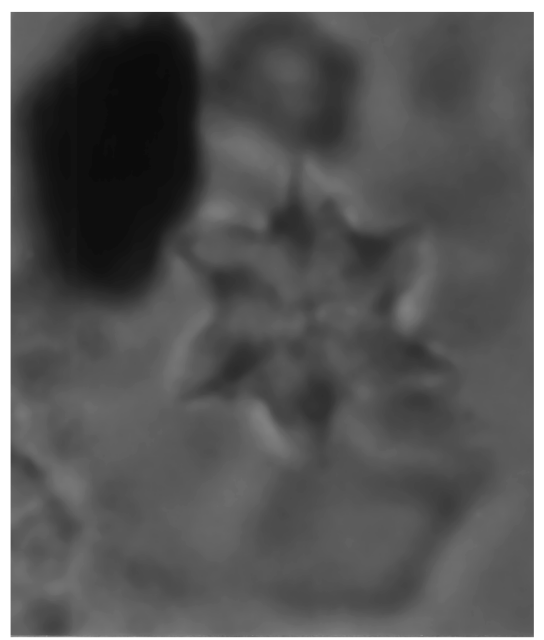

6

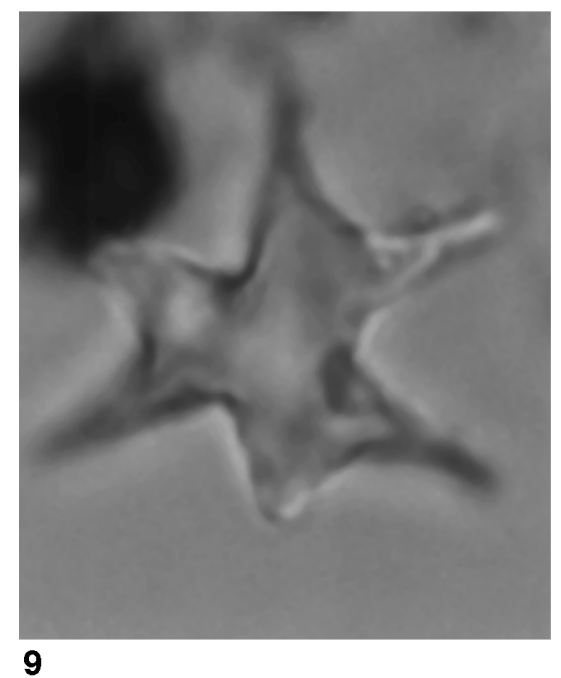

Plate 4. Bar scale $=10 \mu \mathrm{m}$. Magnification approximately 2440×. 1, 2. Liliasterites angularis, Sample 159-960C-26X-CC. 3, 4. Liliasterites atlanticus, Sample 159-959D-67R-2, 105-106 cm. 5, 6. Lithastrinus grillii, Sample 159-959D-66R-4, 77-79. 7, 8. Lithastrinus septenarius, Sample 159-959D-66R-7, 8-11 cm. 9. Marthasterites jucundus, Sample 159-960C-26X-CC. 